\title{
The Itiúba alkaline syenite massif, Bahia State (Brazil): mineralogical, geochemical and petrological constraints- relation to the genesis of rapakivi magmatism
}

\author{
Herbet Conceição ${ }^{a}$, Pierre Sabaté ${ }^{a}$ and Bernard Bonin ${ }^{b}$ \\ a Departamento de Geoquímica, UFBA, 40210 Salvador (Bahia), Brazil \\ ${ }^{b}$ Département des Sciences de la Terre, UPS, F-91405 Orsa y Cédex, France
}

(Received November 20, 1989; revised and accepted July 5, 1990)

\begin{abstract}
Conceição, H., Sabaté, P. and Bonin, B., 1991. The Itiúba alkaline syenite massif, Bahia State (Brazil): mineralogical, geochemical and petrological constraints-relation to the genesis of rapakivi magmatism. In: I. Haapala and K.C. Condie (Editors), Precambrian Granitoids-Petrogenesis, Geochemistry and Metallogeny. Precambrian Res., 51: $283-314$.
\end{abstract}

Numerous alkaline massifs occur throughout the state of Bahia (Brazil). Isotopic dates fall into two age groups: Brasiliano $(0.45-0.70 \mathrm{Ga})$ and Trans-Amazon $(1.8-2.1 \mathrm{Ga})$ ones. Brasiliano alkaline provinces comprise a silica-undersaturated association, with related volcanic rocks; their emplacement is always controlled by fault zones.

Trans-Amazon alkaline massifs are characterized by large plutons (more than $100 \mathrm{~km}^{2}$ ) of $\mathrm{K}$-rich syenite and granite associated with mafic cumulates and abundant dyke swarms. No associated volcanic rocks have been so far recorded. The shape of the plutons varies as a function of their location within the São Francisco Craton. In its northeastern and southern parts, syenite massifs are elongated, trending N-S, while in its western part, they are emplaced as circular bodies displaying contact metamorphic aureoles. The presence of older (Archaean?) alkaline rocks cannot be ruled out, as some granulitic facies display syenite compositions.

The Itiúba massif provides a good example of Proterozoic alkaline syenite. Located in the northern part of the São Francisco Craton, this $150-\mathrm{km}$-long pluton covers $1800 \mathrm{~km}^{2}$ in area. Whole-rock Rb-Sr isotopic data yield a lower Proterozoic age.

A N-S-trending foliation at the margins is gradually replaced by isotropic textures toward the core. Two sets of faults, both of Trans-Amazonian age, have been defined: N-S-trending reverse faults, accompanied by intense mylonitization, and younger NW-trending arcuate transcurrent faults related to a NE-SW compressive regime.

Alkaline syenites constitute $98 \%$ of the exposures and are medium- to coarse-grained clinopyroxene-amphibole, hypersolvus leucratic rocks. Cumulates are represented by mafic layers and clinopyroxene-apatite enclaves. Dykes are composed of alkaline syenite, hypersolvus and transsolvus quartz-syenites and alkaline granites. Syenites are metaluminous and rich in $\mathrm{K}, \mathrm{Mg}, \mathrm{P}, \mathrm{Ti}$ and $\mathrm{Ba}$, and their geochemical trends are controlled by alkali feldspar, clinopyroxene, apatite and $\mathrm{Fe}-\mathrm{Ti}$ oxide fractionation. Oxidizing conditions are reflected by the weak variation in the $m g$-ratio, the reverse $\mathrm{Fe} \rightarrow \mathrm{Mg}$ mineral zonation, the synchronous precipitation of oxides and clinopyroxene in mafic layers and the late development of uralitic amphibole and low-Ti phlogopite. Temperatures for oxide equilibration of $930-880^{\circ} \mathrm{C}$ are compatible with the hypersolvus feldspar mineralogy. The evolution of feldspar mineralogy is a good indicator of varying thermodynamical conditions during late-stage crystallization of the pluton. Minimum values for initial crystallization temperature have been evaluated at $950^{\circ} \mathrm{C}$.

Structural and petrological results indicate that the presently exposed syenite massif represents the roof of a Proterozoic magma chamber, emplaced in granulite-gneiss formations. Rapakivi magmatism may represent disrupted and floating portions of the roof of earlier magma chambers refilled by new syenite-granite melts.

\section{Introduction}

Alkaline plutonic rocks are defined by high alkali contents relatively to silica and alumina (Sørensen, 1974; Bonin and Giret, 1985). They are emplaced at various structural levels 
(Bonin, 1986), but especially at shallow depths (between 0.5 and $2 \mathrm{~km}$ ), where they define ring-complexes, these being roots of caldera volcanoes. However, petrological studies of alkaline ring-complexes (Bowden and Turner, 1974; Bonin, 1980; Giret, 1983) have demonstrated that liquids forming ring-complexes were produced by magma differentiation at an earlier stage in a reservoir emplaced at greater depths $(8-20 \mathrm{~km})$. Thus, geological and petrological studies of deep alkaline reservoirs will provide insights into liquid evolution and the acquisition of (per) alkaline characteristics.

Alkaline magmatic activity takes place in within-plate settings. Thus, uplift and erosion processes are weak, so that, if an erosion rate of $0.1 \mathrm{~mm} \mathrm{a}^{-1}$ is assumed, it takes at least 80 $200 \mathrm{Ma}$ for 8 to $20 \mathrm{~km}$ deep magma reservoirs to reach the surface. Thus, in any given alkaline magmatic province, it is not possible to simultaneously observe the shallow structural levels of caldera volcanoes and ring-complexes, and the deep magma reservoir. Precambrian alkaline provinces are therefore of interest, as they are located in deeply eroded cratons. Significant examples studied include the Pikes Peak Batholith (Colorado, U.S.A.) (Barker et al., 1975), Rogaland Province (S. Norway) (Duchesne, 1984) and the Rapakivi Magmatic Province (Finland and U.S.S.R.) (Vorma, 1976; Haapala, 1988). We present here results from the alkaline syenite Itiúba massif in Bahia State, Brazil.

\section{Alkaline magmatic provinces in Bahia State (Brazil)}

Alkaline magmatism was widespread in Bahia State (Brazil) during Precambrian times (Conceição and Bonin, in prep.). Within the alkaline magmatic province, two age groupings have been identified: Brasiliano (0.45$0.70 \mathrm{Ga})$ and Trans-Amazon $(>1.8 \mathrm{Ga})$. In South America, the Brasiliano orogenic cycle corresponds to the Pan-African orogenic cycle in Africa, and Trans-Amazon correlates with the Eburnean.

Brasiliano alkaline formations are made up of small ring-complexes and dyke swarms. Their emplacements were controlled by largescale faulting which occurred at the end of the Brasiliano orogenic episode and during the consolidation of the São Francisco Craton. Rock types are dominantly plutonic (gabbros, diorites, nepheline syenites), with minor amounts of volcanic products (trachytes, phonolites). Silica-undersaturated nepheline syenites are essentially metaluminous (miaskitic), and some examples of peralkaline (agpaiitic) nepheline syenites have been observed.

Trans-Amazon alkaline provinces constitute huge batholithic $\left(>100 \mathrm{~km}^{2}\right.$ ) syenite massifs (Barbosa and Costa, 1973; Inda and Barbosa, 1978; Marinho et al., 1979; Conceição et al., 1989a, b), as well as subordinate small stocks (Tanner de Oliveira and Jesus, 1979; Silva et al., 1988; Leite and Froés, 1989). All massifs intrude Trans-Amazon mobile belts and their emplacement was controlled by largescale Archaean structural features. They are characterized by the presence of mafic cumulates and absence of volcanic rocks.

Among the Bahian Trans-Amazon alkaline massifs, the Itiúba syenite massif is the largest. Located in the north-central part of Bahia State, it constitutes a north-south trending, elongated body covering an area of $1,800 \mathrm{~km}^{2}$. It has been mapped previously by Delgado and Souza (1975), and by Inda et al. (1976). The $\mathrm{Rb}-\mathrm{Sr}$ whole-rock isochron method has yielded an age of $2.1 \mathrm{Ga}$, which is interpreted as age of emplacement (Conceição, 1990).

In this paper, we shall focus on petrographical, mineralogical and geochemical aspects of exposed rock types in the Itiúba massif. Their petrogenetic and tectonic significance will be discussed, with emphasis on their relation to the genesis of rapakivi magmatism. 


\section{Geological setting}

Located in the northern-central part of the São Francisco Craton, the Itiúba syenite massif is an elongate north-south trending, $150 \mathrm{~km}$ long and $12 \mathrm{~km}$ wide, complex (Fig. 1). The massif intrudes Early Proterozoic gneiss-granulite formations of the Salvador-Curaçà $(>2.1$ $\mathrm{Ga}$ ) mobile belt (Mascarenhas, 1979).

The mobile belt was emplaced between the two cratonic nuclei of Remanso (also named Lençois) and Serrinha, which were consolidated before the Jéquié Archaean ( $>2.5 \mathrm{Ga}$ ) orogenic episode (Mascarenhas, 1979). Granulite and gneiss formation of the SalvadorCuraçà mobile belt have undergone several phases of deformation (Delgado and Souza, 1975; Inda et al., 1976; Hasui et al., 1982; Jardim de Sá et al., 1982), the major phase being characterized by a north-south trending foliation (D'el R. Silva, 1985). According to these authors, the mobile belt is made up of two discrete metamorphic units. The lower unit is composed of supracrustal rocks, with graphiteand/or garnet-bearing quartz-feldspar paragneisses, amphibolites and quartzites. The upper unit is made up of orthogneisses and basic to ultrabasic massifs with $\mathrm{Cu}$ and $\mathrm{Cr}$ ore bodies. All units are intruded by late basic dykes.

In Bahia State, Brasiliano metamorphic and folding events have not affected mineral or whole-rock isotopic systems, implying that the São Francisco Craton behaved as a rigid block during the Brasiliano orogeny, which is better documented in the surrounding states.

The emplacement of the syenite massif is correlated with the last phase of deformation observed in the Curaçá Valley (D'el R. Silva, 1985). Sharp contacts against Early Proterozoic formations locally display features of magmatic stoping in the $300 \mathrm{~m}$ wide marginal zone. The associated Pedra Solta granite (Conceição and Sabaté, 1986; Celino, 1986) displays lobate mutual contacts (Fig. 1), implying more or less synchronous time of emplacement: in the contact zone, abundant flat- tened syenite enclaves and parallelism of alkali feldspar xenocrysts within the granite mass suggest that the granitic magma was emplaced while the already consolidated syenite was yet viscous (Conceição et al., 1989a).

Syenitic rocks show a consistent north-south trending foliation, marked by mafic mineral alignment. The foliation is well developed at the contacts and gradually passes into a core having an isotropic texture. Two groups of major fault patterns have been recognized (Domingues Alonso and Conceição, 1986; Conceição et al., 1989b ).

The first major class trends north-south and corresponds to reverse faults with westward dip, implying an east-west compressive regime. Within the syenitic rocks, the associated deformation is marked by mylonitization and development of a thick shear zone along the eastern boundary of the massif (Fig. 1). Syntectonic granitic dykes (Bastos Leal, 1986) and later pegmatites follow the same trend.

A second class is represented by arcuate NW-SE trending faults which cut the N-S fractures, the granitic dykes and the pegmatites. The eastern boundary of the massif is displaced by these faults, whereas along the western boundary, $\mathrm{N}-\mathrm{S}$ reverse faults were rejuvenated by a dextral strike-slip movement. Within the syenitic rocks, the deformation is marked by vertical faults with a significant horizontal component, inducing severe textural transformations including narrow bands of ultra-mylonite, and compatible with a NESW compressive regime (Conceição et al., $1989 \mathrm{~b}$ ). Since they displace intrusive contacts, these faults post-date melt emplacement and crystallization. They are characterized by solidstate deformation of rocks, but host late-stage, highly differentiated syenite and granite dykes and, therefore, are interpreted as having been active during the late stages of syenite emplacement.

The $\mathrm{N}-\mathrm{S}$ trending elongation of the Itiúba syenite massif corresponds to a major fracture zone, while the arcuate fault pattern is con- 

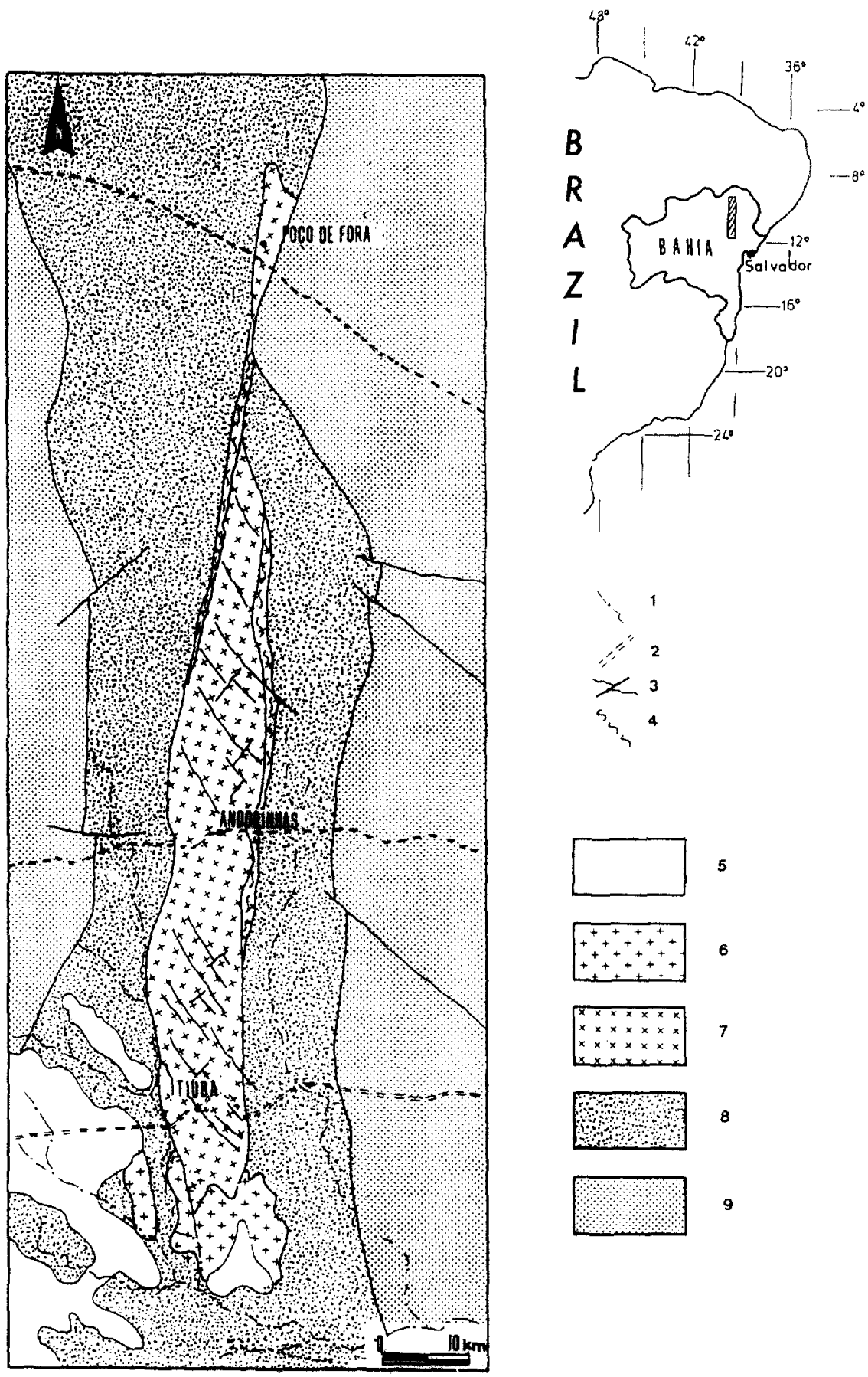

\section{5}
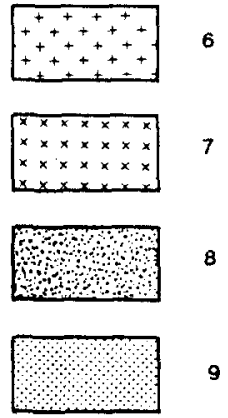

9

Fig. 1. Geographical location and geological sketch map of the Itiúba massif, after the Geological Map of Bahia State (Inda and Barbosa, 1978): $1=$ Itapicuru river; $2=$ main roads; $3=$ faults; $4=$ shear zones; $5=$ Quaternary sediments; $6=$ Pedra Solta granite; $7=$ Itiúba alkali-feldspar syenite; $8=$ Salvador Curaçá mobile belt; $9=$ diatexites and metatexites. Because of the scale, relatively small features such as dykes are not represented. 
trolled by local conditions during the cooling (and uplift?) of the pluton. Other large syenite bodies may have been emplaced at the same time under the same regional stress field. Conceição et al. (1989b) have suggested that the syenite massifs follow older major discontinuities initiated during Early Proterozoic or Archaean time.

\section{Petrographical, textural and mineralogical aspects}

More than $98 \%$ of the syenite massif consists of hypersolvus leucocratic alkali-feldspar syenites with subordinate mesocratic and hololeucocratic syenites. The remaining $2 \%$ are mafic cumulates referred to as layers, microrhythmites and enclaves, and (holo)leucocratic dykes (Fig. 2).

Modal data produce a trend following the evolution defined for the silica-saturated alkaline suite by Lameyre and Bowden (1982) and Bowden et al. (1984). However, the range of modal compositions is more limited than in classical alkaline provinces, such as Niger-Nigeria (Lameyre and Bowden, 1982), Oslo Rift (Oftedahl, 1978) and Corsica (Bonin, 1980).

\section{Syenites}

The alkali-feldspar syenites display a medium- to coarse-grained phaneritic texture, with anisotropy marked by a N-S trending foliation displayed by alkali feldspars. The dominant texture is allotriomorphic, with alkali feldspar forming the major mineral phase, while other minerals occupy spaces between adjacent feldspar crystals (Fig. 3). This is interpreted as indicating magmatic accumulation and compaction processes (Conceição, 1990). Moreover, contacts between adjacent alkali-feldspar crystals are at angles of 100 to $120^{\circ}$, implying a late-stage reequilibration (Hunter, 1987). As no Brasiliano-age metamorphism is recorded in the area, textural features are assigned to emplacement and consolidation processes.

Major minerals in the paragenesis are, in ap-

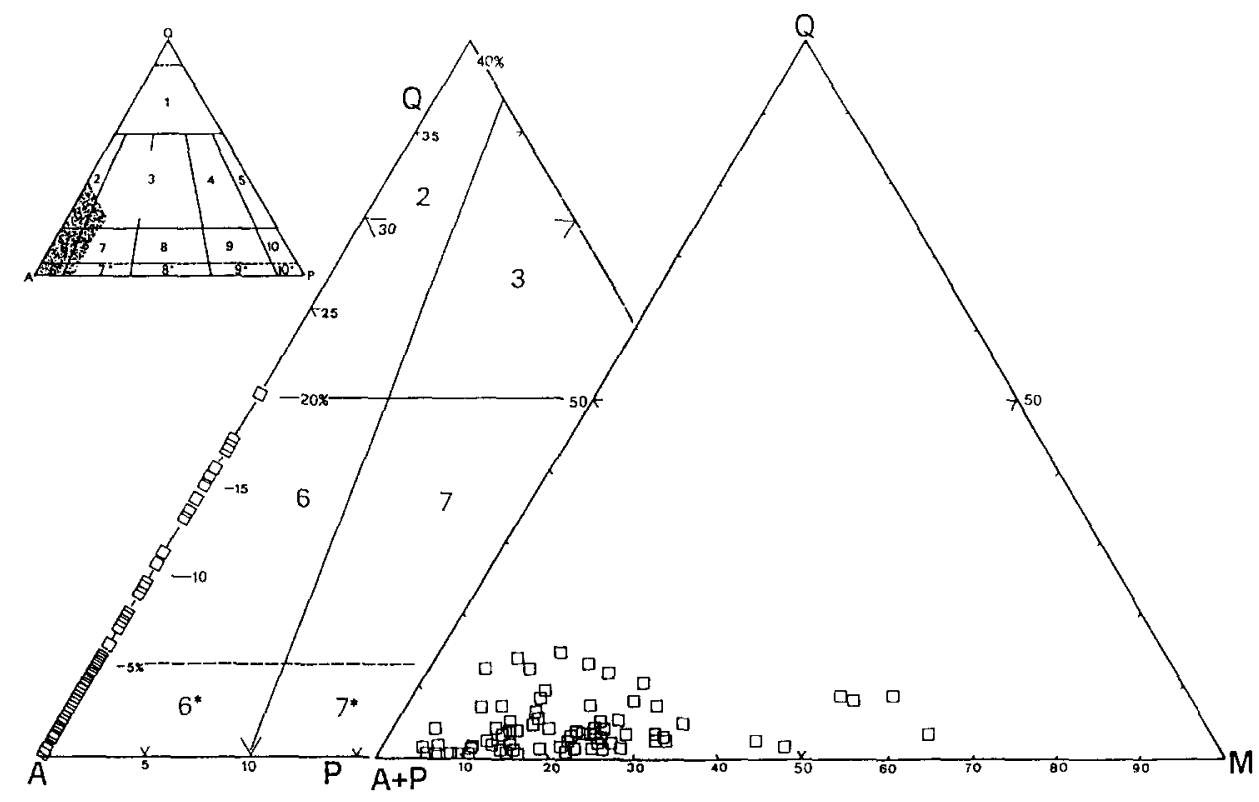

Fig. 2. Q-A-P and Q-A + P-M plots (Streckeisen, 1976) for the alkali-feldspar syenite (open squares): $Q=$ quartz: $A=$ alkali feldspar; $P=$ plagioclase; $M=$ mafic minerals. Note the restricted range of compositions within the alkali-feldspar syenite field (shaded), and the wide range of colour index (from 0 to 65 ). 


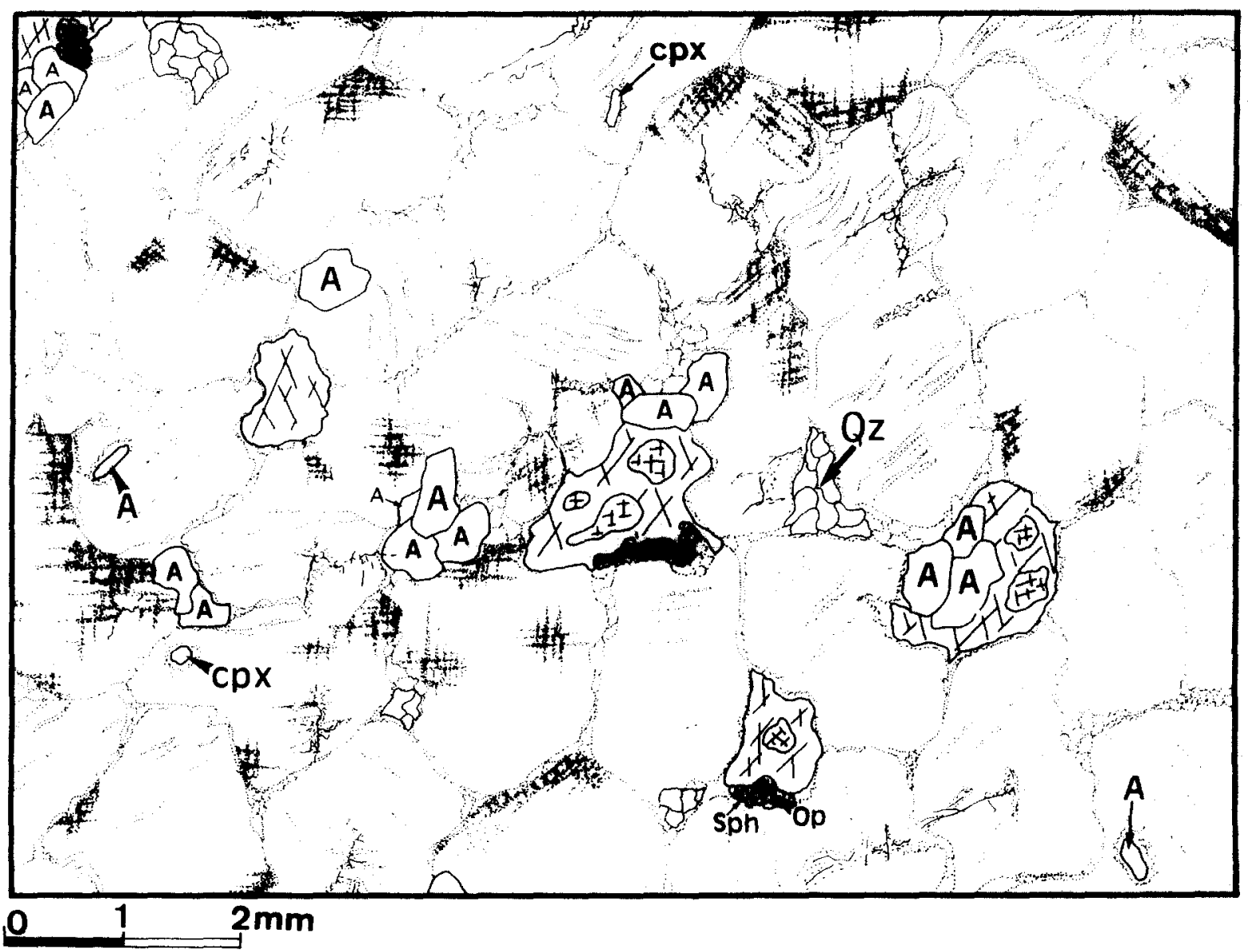

Fig. 3. Textural relationships within alkali-feldspar syenites (scale indicated by the 2-mm bar). Albite lamellae and occasional cross-hatched twinning in alkali feldspar crystals are represented by dotted patterns; amphibole crystals can be recognized by lines representing their preferred cleavage planes. $c p x=$ clinopyroxene; $A=$ apatite; $O p=$ oxide minerals; $Q z=$ quartz; $s p h=$ titanite.

proximately decreasing order of abundance: alkali feldspar, clinopyroxene, amphibole, quartz and Fe-Ti oxides. Accessory minerals include: apatite, zircon, titanite, mica and allanite.

\section{Mafic cumulates}

Mafic layers display a medium-grained phaneritic texture, with the main paragenesis consisting of perthitic alkali feldspar, clinopyroxene, amphibole and apatite. Minor minerals are Fe-Ti oxides, titanite, zircon, pyrite and allanite. Mineral components and grain size are similar to those in syenites, but the relative proportions differ, suggesting magmatic accumulation of clinopyroxene, apatite and accessory minerals in an amphibole-rich matrix (Conceição et al. 1989a).

Discontinuous mafic layers are present throughout the massif, implying large-scale crystal settling. They constitute roughly parallel units, with metre-scale lengths and centimetre-scale widths, some of them displaying spindle shapes, and are sometimes accompanied by minor rhythmites.

Two types of mafic layers have been observed. The first is isomodal throughout the layer, while the second grades upward into the syenitic host rock. This upward gradational 
second type of mafic layer generally dips gently to the west, suggesting that the most apical part of the intrusion is exposed in the western part.

Small-scale layered structures are attributed to crystallization stages inside stagnant zones and may reflect thermal oscillations (Thy et al., 1987). The presence of cumulus apatite provides evidence for early phosphorus-saturation of the melt (Watson, 1979, 1980).

\section{Enclaves}

Three types of enclaves are distinguished on the basis of mineralogy and geometry:

(1) Basement rocks (granulites and gneisses ) form angular enclaves and are present in the marginal zones of the massif, indicating local magmatic stoping.

(2) Quartz-diorite to monzonite enclaves have a tabular shape and centimetre-scale length. Decreasing grain size from core to rim reflects their primary intrusive characteristics and a strong thermal gradient between enclave melts and host syenite at the time of mixing (Didier, 1973).

(3) Ellipsoidal, centimetre-scale mafic enclaves, with amphibole reaction rims. These constitute apatite-clinopyroxene cumulates, with amphibole, $\mathrm{Fe}-\mathrm{Ti}$ oxides and biotite as intercumulus mineral phases. They have exactly the same composition as the basal zone of the gradational layers and record mechanical disruption of the early cumulative phase, which formed prior to alkali-feldspar crystallization (Conceição et al., 1989a).

\section{Dykes}

Several generations of dyke swarms intrude the syenites. They include:

(1) White granular dykes with centimetrescale widths and indistinct contacts, composed of leucocratic hypersolvus alkali-feldspar syenites, similar to their syenitic host rocks; they may represent residual liquids extracted by filter-pressing.
(2) Pink to red dykes with sharp, rectilinear contacts and chilled margins, and consisting of alkali-feldspar quartz-syenite and alkali-feldspar granite; they are characterized by grains of perthitic K-feldspar and albite. The association of two discrete alkali feldspars suggests aqueous fluid enrichment of the residual magma and consequent lowering of the solidus temperature. The result was a transition from hypersolvus through transsolvus to subsolvus conditions (Tuttle and Bowen, 1958; Martin and Bonin, 1976).

(3) Pegmatitic dykes with sharp rectilinear contacts, often displaying zonation, with a quartz-rich core, and complex margins in which alkali-feldspar-rich zones (sometimes amazonitic) alternate with amphibole-biotite-rich zones. Mafic minerals and some alkali-feldspar crystals have crystallized perpendicular tot the contacts. Two discrete alkali feldspars, albite and microcline, characterize the subsolvus type of crystallization.

The major mineral phases-alkali feldspar, clinopyroxene, amphibole, mica, and $\mathrm{Fe}-\mathrm{Ti}$ oxides-have been analyzed for major elements and $\mathrm{Ba}, \mathrm{Sr}$ with Camebax electron microprobes at Laboratoire de Microanalyse Electronique, Université Paris-Sud, Orsay, and at Camparis, Université Pierre-et-Marie Curie, Paris. The analytical details are given by Bonin (1988), and Bonin and Platevoet (1988).

\section{Alkali feldspars}

Some separated crystals were analyzed by XRF techniques, and single crystals of alkali feldspars have been studied by electron microprobe. Representative chemical data are listed in Tables 1 and 2. Alkali feldspars record different types of crystallization, ranging from hypersolvus to transsolvus and subsolvus. The crystallographic structures of the alkali feldspars are triclinic, always with microcline and low albite. 


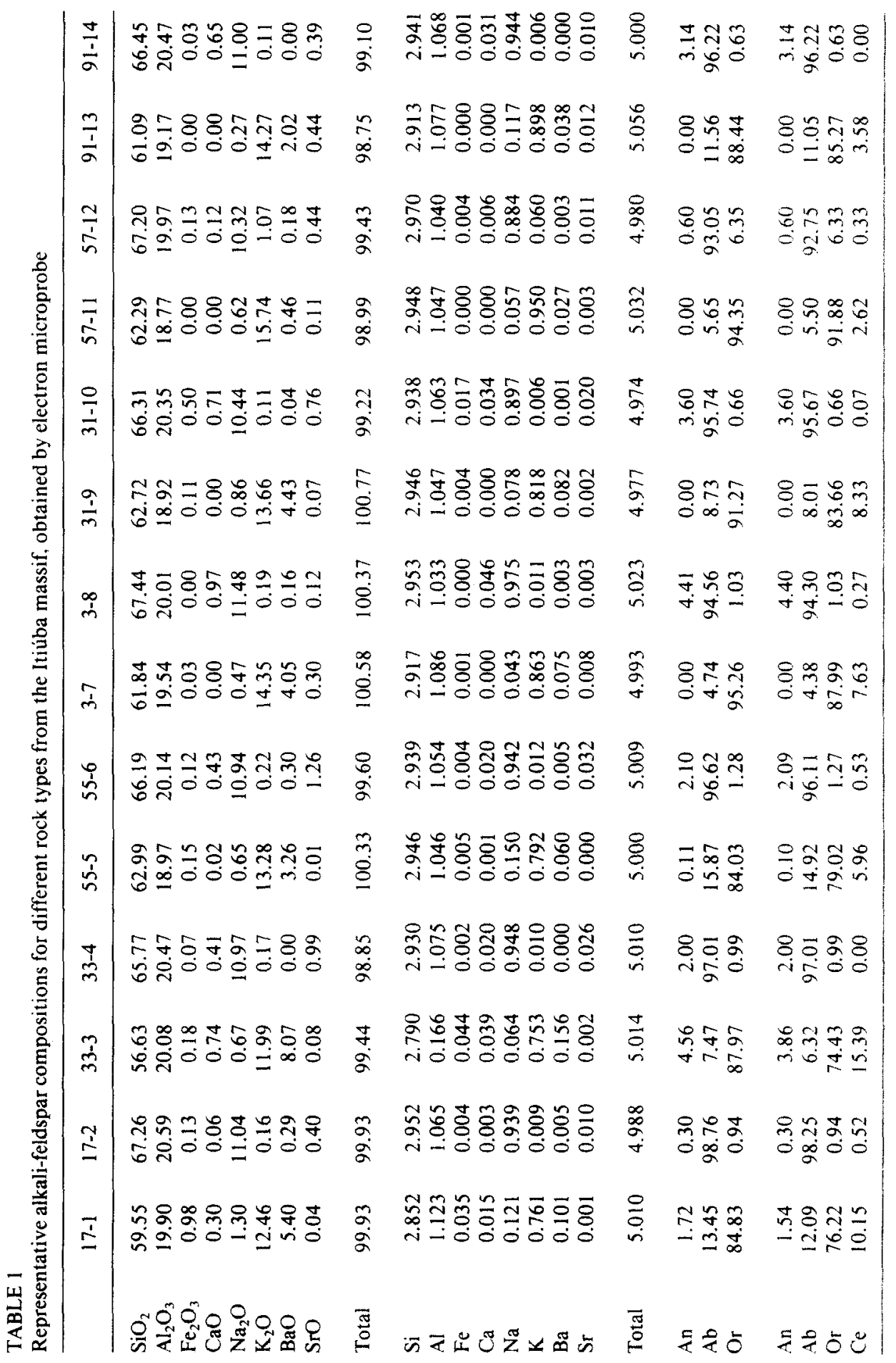




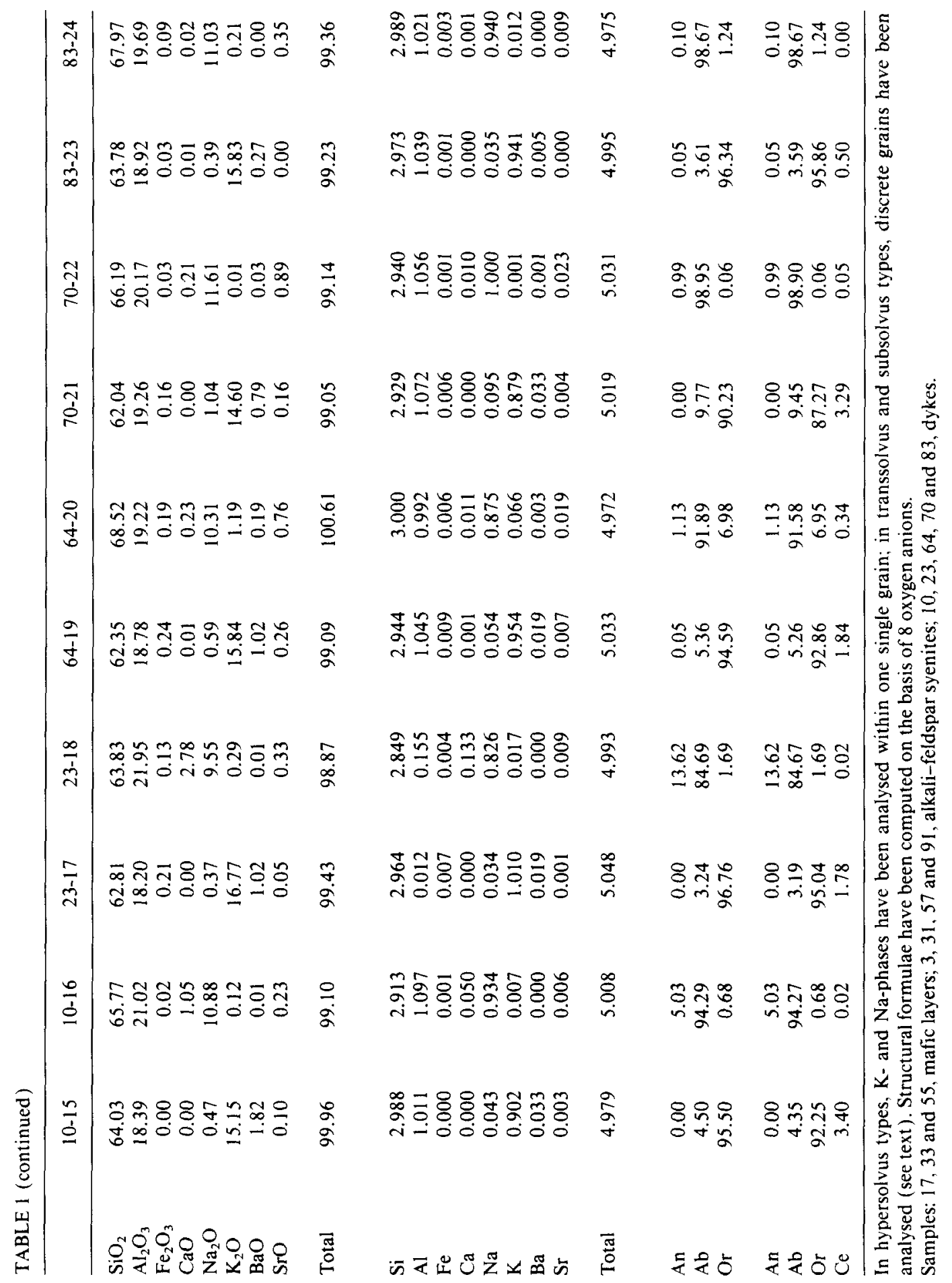


TABLE 2

Alkali feldspar compositions obtained on mineral separates by XRF techniques

\begin{tabular}{lrlrrrr}
\hline & 224 & 57 & 204 & 10.02 & \multicolumn{1}{c}{72} & \multicolumn{1}{c}{318} \\
\hline $\mathrm{SiO}_{2}$ & 63.87 & 65.03 & 66.34 & 65.05 & 64.70 & 65.46 \\
$\mathrm{TiO}_{2}$ & 0.02 & nd & 0.06 & \multicolumn{1}{c}{ nd } & 0.02 & nd \\
$\mathrm{Al}_{2} \mathrm{O}_{3}$ & 18.71 & 19.01 & 0.34 & 18.95 & 18.53 & 18.60 \\
$\mathrm{Fe}_{2} \mathrm{O}_{3}$ & nd & nd & 0.05 & 0.22 & 0.27 & \multicolumn{1}{c}{ nd } \\
$\mathrm{MgO}$ & nd & nd & 0.44 & nd & 0.04 & nd \\
$\mathrm{CaO}$ & 0.20 & 0.06 & 3.79 & 0.10 & 0.17 & nd \\
$\mathrm{Na}_{2} \mathrm{O}$ & 3.12 & 3.54 & 10.46 & 4.20 & 2.91 & 2.42 \\
$\mathrm{~K}_{2} \mathrm{O}$ & 11.30 & 11.10 & 0.19 & 10.23 & 11.85 & 12.82 \\
$\mathrm{P}_{2} \mathrm{Os}$ & 0.34 & 0.17 & 0.40 & 0.12 & 0.14 & 0.80 \\
$\mathrm{LOI}$ & 0.53 & 0.32 & 100.45 & 0.42 & 0.49 & 0.41 \\
& & & & & & \\
$\mathrm{Total}$ & 98.09 & 99.25 & 99.29 & 99.29 & 99.12 & 99.79 \\
$\mathrm{Ba}$ & 5000 & 5000 & 4342 & 7020 & 2843 & 124 \\
$\mathrm{Sr}$ & 5000 & 5000 & 1346 & 1785 & 754 & 43 \\
$\mathrm{Rb}$ & 373 & 286 & 364 & 490 & 512 & 4995 \\
& & & & & & \\
$\mathrm{Or}$ & 69.7 & 67.1 & 63.1 & 72.2 & 61.3 & 77.7 \\
$\mathrm{Ab}$ & 29.3 & 32.5 & 34.7 & 26.9 & 38.2 & 22.3 \\
$\mathrm{An}$ & 1.0 & 0.4 & 2.2 & 0.9 & 0.5 & 0.0 \\
\hline
\end{tabular}

Structural formulae have been calculated on the basis of 8 oxygen anions.

Samples: 224, mafic layer; 57 and 204, alkali-feldspar syenite; 10.02 and 72 , pink dyke; 318 , amazonite dyke.

\section{Hypersolvus facies}

In the hypersolvus syenites, pink to red perthitic alkali-feldspar crystals are generally inclusion-poor, while in the mafic layers, alkalifelspar crystals are white and inclusion-rich. In film-perthites, the albite is always white and seldom twinned. Optically homogeneous crystals are consistently cryptoperthitic. In some cases, exsolved albite comprises the dominant phase (antiperthite).

In order to obtain the average compositions, we have separated some crystals from a mafic layer (sample 224), two syenites (samples 57 and 204), and three pegmatite dykes (large pink crystals: samples 72 and 10.2; and green amazonitic crystals: sample 318 ) (Table 2). In addition, chemical analyses of the different phases inside single grains have been performed (Table 1 ).

Separated alkali-feldspar crystals yield a fairly constant major element composition, with high $\mathrm{K}_{2} \mathrm{O} / \mathrm{Na}_{2} \mathrm{O}$ ratios from about 3 to 5 . Low $\mathrm{P}_{2} \mathrm{O}_{5}$ and L.O.I. values are due to apatite inclusions. K-rich alkali feldspars range from $\mathrm{Or}_{70}$ in mafic layer 224 to $\mathrm{Or}_{63}$ in syenite 204 , and from $\mathrm{Or}_{61}$ to $\mathrm{Or}_{78}$ in pegmatite dykes. $\mathrm{Ba}$, $\mathrm{Rb}$ and $\mathrm{Sr}$ display a compositional trend from $\mathrm{Sr}$ - and Ba-rich, and Rb-poor compositions (mafic layer 224) to Sr- and Ba-depleted and Rb-enriched compositions (amazonite dyke 318 ). Enrichment and depletion ratios are, respectively, about 15 for Rb, 120 for $\mathrm{Sr}$. Ba behaves more erratically, with high values ( 2800 $7000 \mathrm{ppm}$ ) in the mafic layer, syenites and two pegmatite dykes, and a very low value (125 $\mathrm{ppm}$ ) in the amazonite dyke. Fractionation of major and minor element contents is well illustrated in the field by the two pegmatite dykes 10.02 and 72 , for which cross-cutting relations indicate the succession: first 10.02 , then $72 ; \mathrm{K}$ and $\mathrm{Rb}$ increase, while $\mathrm{Na}, \mathrm{Sr}$ and $\mathrm{Ba}$ decrease.

Within single crystals, major and trace elements are partitioned between the K-rich and the Na-rich phases. The K-rich phase, ranging from $\mathrm{Or}_{74}$ (in mafic layers) to $\mathrm{Or}_{96}$ (in dykes), is always anorthite-poor (less than $3.9 \%$ in mafic layers, near $0.0 \%$ in other samples ), and Ba-rich (up to $8.1 \mathrm{wt} \% \mathrm{BaO}$ corresponding to $15.4 \%$ celsian molecule in the mafic layers, and between 0.33 and $4.4 \mathrm{wt} \% \mathrm{BaO}$ corresponding to 0.6 to $8.3 \mathrm{wt} \%$ of celsian molecule in syenites). An evolution from $\mathrm{Ba}$ - and $\mathrm{Ca}$-rich compositions toward $\mathrm{Ba}$ - and $\mathrm{Ca}$-depleted compositions can be observed from sample to sample, as well as from crystal to crystal within a sample, thus substantiating the role of K-rich alkali feldspar in $\mathrm{Ba}-\mathrm{Ca}$ fractionation. Iron, analyzed as total $\mathrm{Fe}_{2} \mathrm{O}_{3}$, is also present: in mafic layers, white alkali feldspars can contain up to $1.2 \mathrm{wt} \% \mathrm{Fe}_{2} \mathrm{O}_{3}$, while in syenites, pink to red alkali feldspars contain only 0.0 to $0.5 \mathrm{wt} \%$ $\mathrm{Fe}_{2} \mathrm{O}_{3}$.

The Na-rich phase is chemically pure low albite with less than $2 \%$ anorthite, $1 \% \mathrm{~K}$ endmember, and $0.5 \%$ celsian molecule. However, SrO contents can reach $1.3 \mathrm{wt} \%$ in albite of mafic layers and $0.8 \mathrm{wt} \%$ in albite of syenites. 
These values represent approximately $1 \%$ of $\mathrm{Sr}$ $\mathrm{Al}_{2} \mathrm{Si}_{2} \mathrm{O}_{8}$ molecule. Sr contents decrease with differentiation from mafic layers to syenites, illustrating the role of albite in $\mathrm{Sr}$ fractionation. Iron, analyzed as total $\mathrm{Fe}_{2} \mathrm{O}_{3}$, is lower than in the K-rich phase, and ranges from 0.0 to $0.5 \mathrm{wt} \% \mathrm{Fe}_{2} \mathrm{O}_{3}$.

\section{Transsolvus and subsolvus facies}

The late dykes are characterized by textures differing significantly from those of early hypersolvus dykes and syenite host rocks. Some dykes display three types of alkali feldspars: a perthitic alkali feldspar rimmed by K-feldspar, a non-perthitic microcline and an albite, which constitute a "transsolvus" mineralogy (Bonin, 1972). The others display only two types of alkali feldspars: a non-perthitic K-feldspar and an albite, which corresponds to "subsolvus" mineralogy (Tuttle and Bowen, 1958). Both phases exhibit nearly pure end-member compositions. The $\mathrm{K}$-rich phase is $\mathrm{Ba}$-poor microcline. Sodic plagioclase ranges from albite to sodic oligoclase (An 13.6) with SrO less than $0.9 \mathrm{wt} \%$. Iron contents, expressed as total $\mathrm{Fe}_{2} \mathrm{O}_{3}$, are always low (less than $0.25 \mathrm{wt} \%$ $\mathrm{Fe}_{2} \mathrm{O}_{3}$ ).

\section{Clinopyroxene}

Representative chemical analyses of clinopyroxene are presented in Table 3. Only one clinopyroxene phase has been observed within the whole massif. It is present as euhedral mineral inclusions inside either early minerals (e.g. apatite), or late minerals (e.g. alkali feldspar), and is always deep green. In syenite, it is inclusion-poor, whereas in the mafic enclaves, it can contain oxide minerals probably related to oxidation-exsolution processes.

According to the I.M.A. classification (Morimoto, 1989), it is diopside, while in older classical classifications (e.g. Deer et al., 1978), it is salite, characterized by compositions poor in $\mathrm{Ti}$ and $\mathrm{Al}(\mathrm{VI})$ and ranging from $\mathrm{Ca}_{47}-\mathrm{Mg}_{35^{-}}$ (total $\mathrm{Fe}+\mathrm{Mn})_{18}$ to $\mathrm{Ca}_{46}-\mathrm{Mg}_{33}-$ (total
$\mathrm{Fe}+\mathrm{Mn})_{21}$. A weak reverse zonation correlates with increasing amounts of $\mathrm{Si}, \mathrm{Ti}, \mathrm{Mg}$, and $\mathrm{Ca}$, and suggests a moderately oxidizing environment.

This restricted range of variations in clinopyroxene chemical compositions can be compared with other silica-saturated alkaline syenites (Neumann, 1976a; Stephenson and Upton, 1982; Giret, 1983; O'Halloran, 1985). The extremely low $\mathrm{Ti}$ - and $\mathrm{Al}$-contents probably reflect contemporaneous $\mathrm{Fe}-\mathrm{Ti}$ oxide mineral precipitation (Larsen, 1976), as the major cation substitution scheme is $\mathrm{Mg} \rightleftharpoons \mathrm{Fe}^{2+}$ (Fig. 4), which is typical of silica-saturated metaluminous alkaline rocks (Bonin and Giret, 1985).

The augite geothermometer proposed by Lindsley (1983) yields temperatures of $600^{\circ} \mathrm{C}$ suggesting late subsolidus reequilibration effects.

\section{Amphibole}

Green amphibole is ubiquitous throughout the massif. In mafic enclaves, mafic layers, and syenite, it crystallized during late magmatic stages, mainly from early clinopyroxene breakdown (uralitization). In syenitic and subsolvus granitic dykes, amphibole crystallized before and/or during alkali feldspar crystallization, as evidenced by euhedral amphibole crystals enclosed within alkali feldspar crystals. Representative analyses are given in Table 4. Amphiboles have been classified according to the I.M.A. classification (Leake, 1978 ) and three groups of amphibole compositions have been recognized:

(1) Group I consists of Ti-poor edenite and Mg-hornblende, derived by breakdown of Tipoor clinopyroxene. Weak chemical zonation is marked by increasing $\mathrm{Si}$ and $\mathrm{Mg}$ from core to rim. According to Leake (1971, fig. 3), this group falls between the igneous amphibole field and the non-igneous amphibole field.

(2) Group II is made up of amphiboles evolving from edenitic hornblende to Ti-en- 


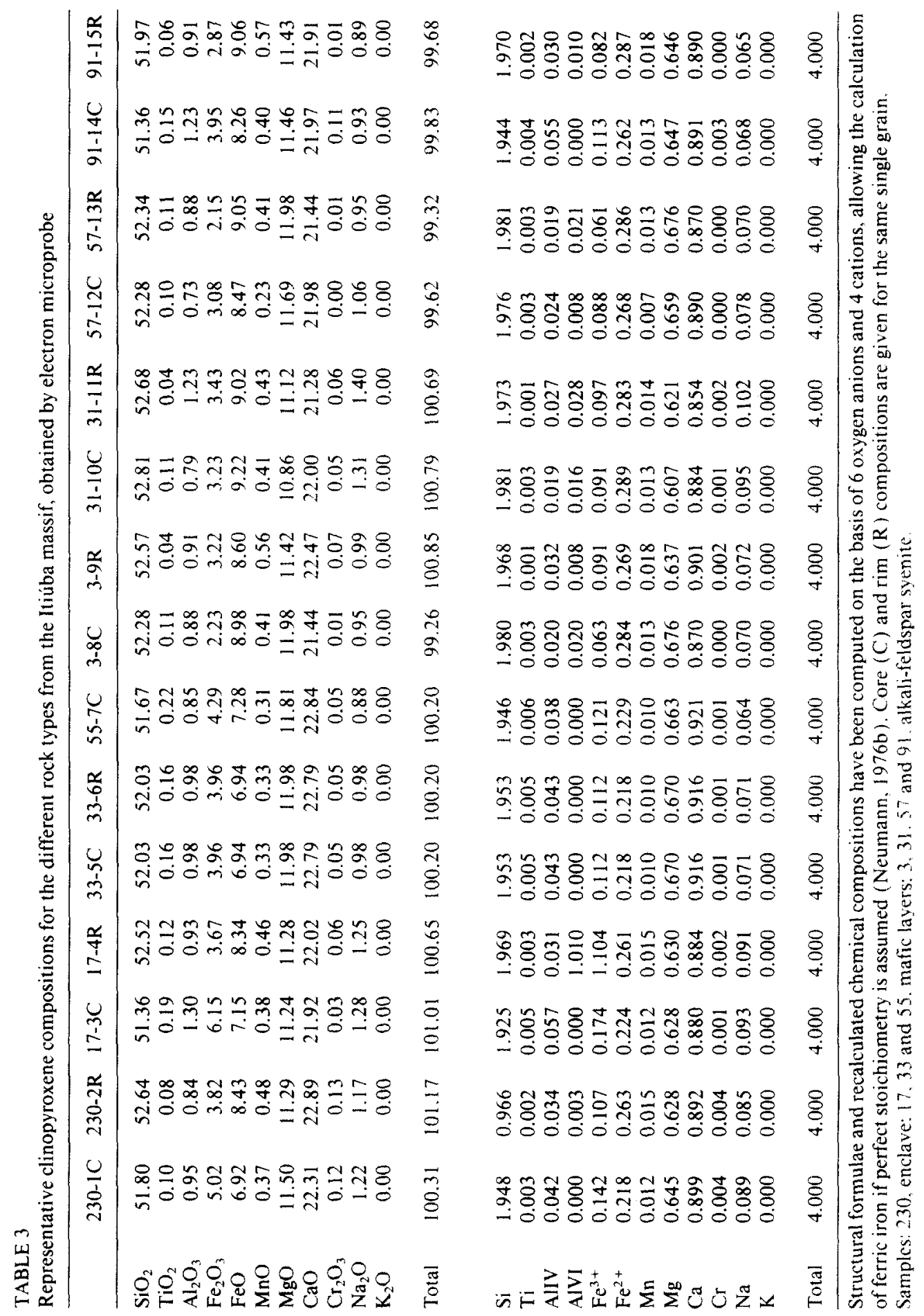



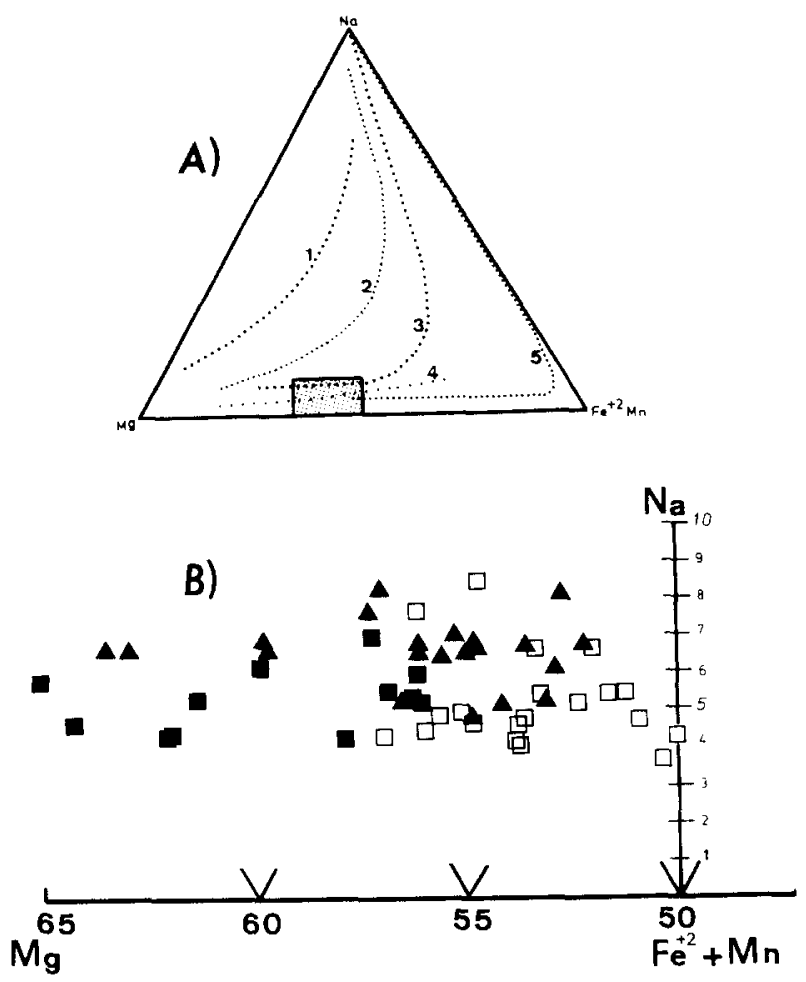

Fig. 4. Clinopyroxene compositions expressed as $\mathrm{Na}-\mathrm{Mg}-$ $\mathrm{Mn}+\mathrm{Fe}^{2+}(\mathrm{A})$, and as $\mathrm{Na}$ vs. $\mathrm{Mg}$ (B). In $\mathrm{A}$, the shaded area represents the compositions of analysed crystals for the whole range of rock types. Trends for different alkaline associations: $1=$ Auvergne (Varet, 1969); $2=$ Uganda (Tyler and King, 1967); 3= South Qôroq, S. Greenland (Stephenson, 1972); 4= Japan alkali basalts (Aoki, 1964); $5=$ Nandewar, Australia (Abbott, 1969). In B, enclaves are represented by filled triangles, mafic layers by filled squares, and alkali-feldspar syenites by open squares.

riched Mg-hastingsitic hornblende. The group is restricted to dykes.

(3) Group III is composed of nearly colourless actinolite, formed either by late transformations of group I edenitic amphiboles, or in mylonitic zones. This group is not represented in the dykes.

Amphibole compositional evolution is illustrated in Fig. 5. Amphiboles follow a similar trend to Si-saturated alkaline rocks (Neumann, 1976a; Giret et al., 1980), with the major substitution law: $\mathrm{Ca}+\mathrm{Al}(\mathrm{IV}) \rightleftharpoons \mathrm{Si}+\mathrm{Na}$ (Giret et al., 1980). A-site occupancy ranges from 0.30 to 0.70 , confirming an edenite-pargasite substitution scheme.

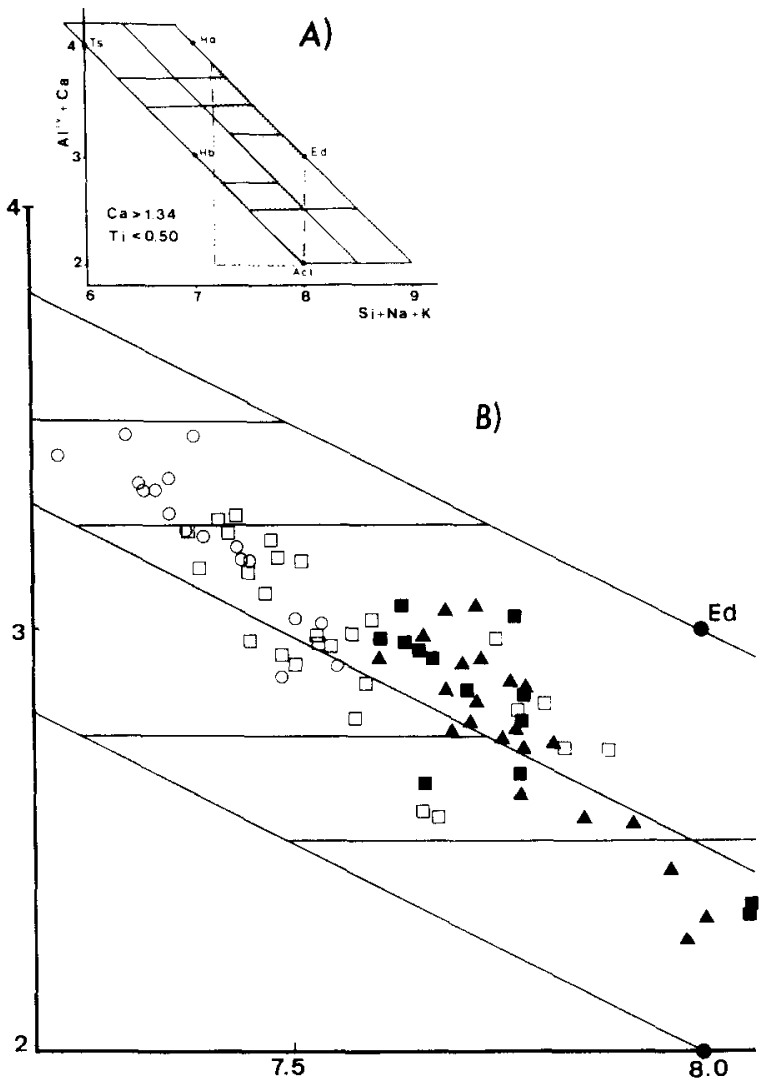

Fig. 5. Amphibole compositions expressed as $\mathrm{Ca}+\mathrm{Al}$ (IV) vs. $\mathrm{Si}+\mathrm{Na}+\mathrm{K}$. A. The shaded area represents the compositions of analysed crystals for the whole range of rock types. End-members: $T s=$ tschermakite; $H a=$ hastingsite; $H b=$ hornblende; $E d=$ edenite; $A c t=$ actinolite. B. Same symbols as in Fig. 3, with dykes as open circles.

Amphibole can play either active or passive roles in magma evolution (Wones and Gilbert, 1981; Bonin and Giret, 1985). In the syenite and its mafic cumulative facies, group I edenite compositions are essentially controlled by clinopyroxene and late fluid compositions. The weak but constant increases in $\mathrm{Mg}$ and $\mathrm{Mn}$ contents from core to rim suggest slightly oxidizing crystallization conditions. Late actinolitic amphiboles of group III are associated with secondary albite and were produced by pervasive low-temperature hydrothermal alteration, probably accompanying late shearing episodes and predating dyke emplacement.

In the dykes, group II compositional evolu- 


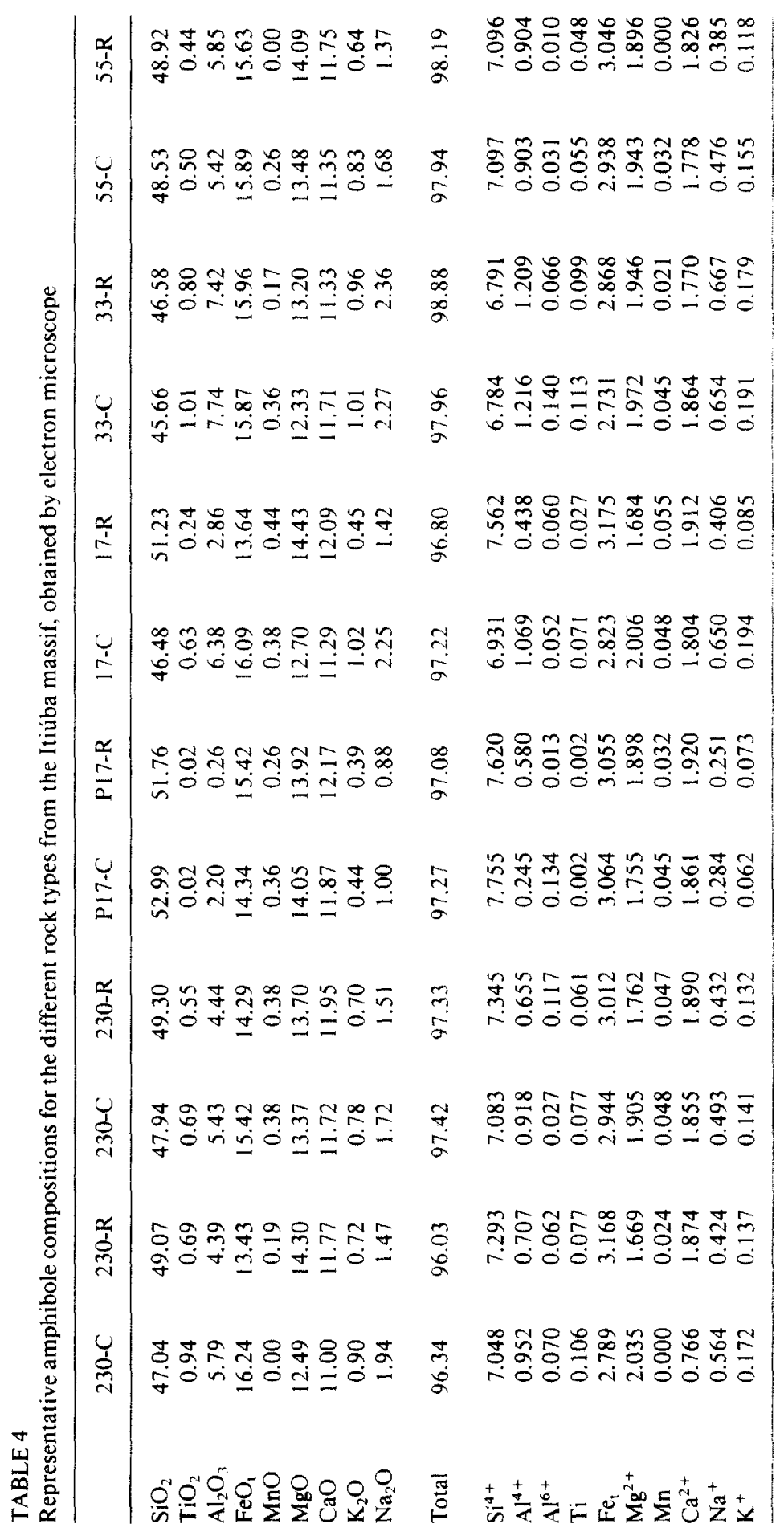




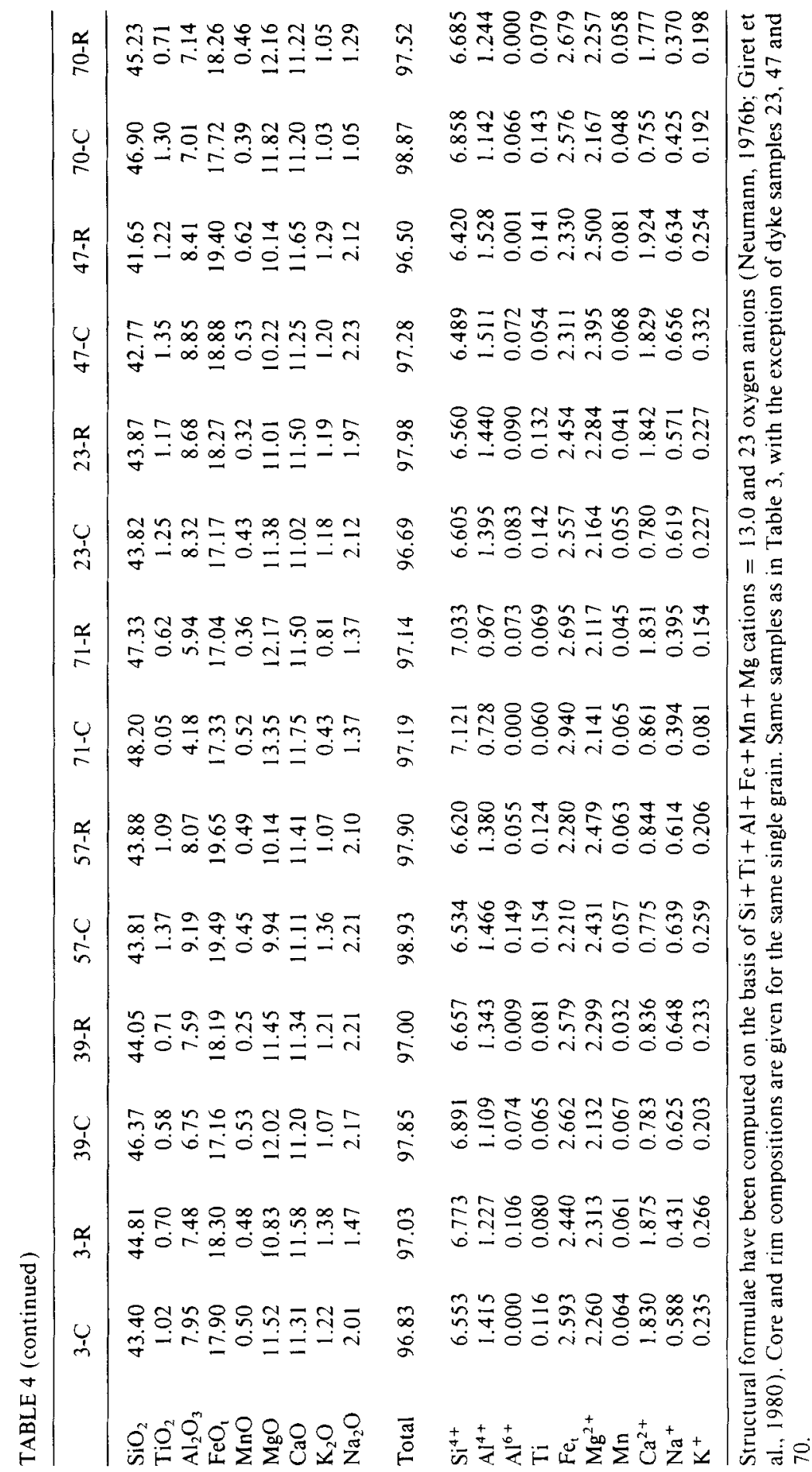




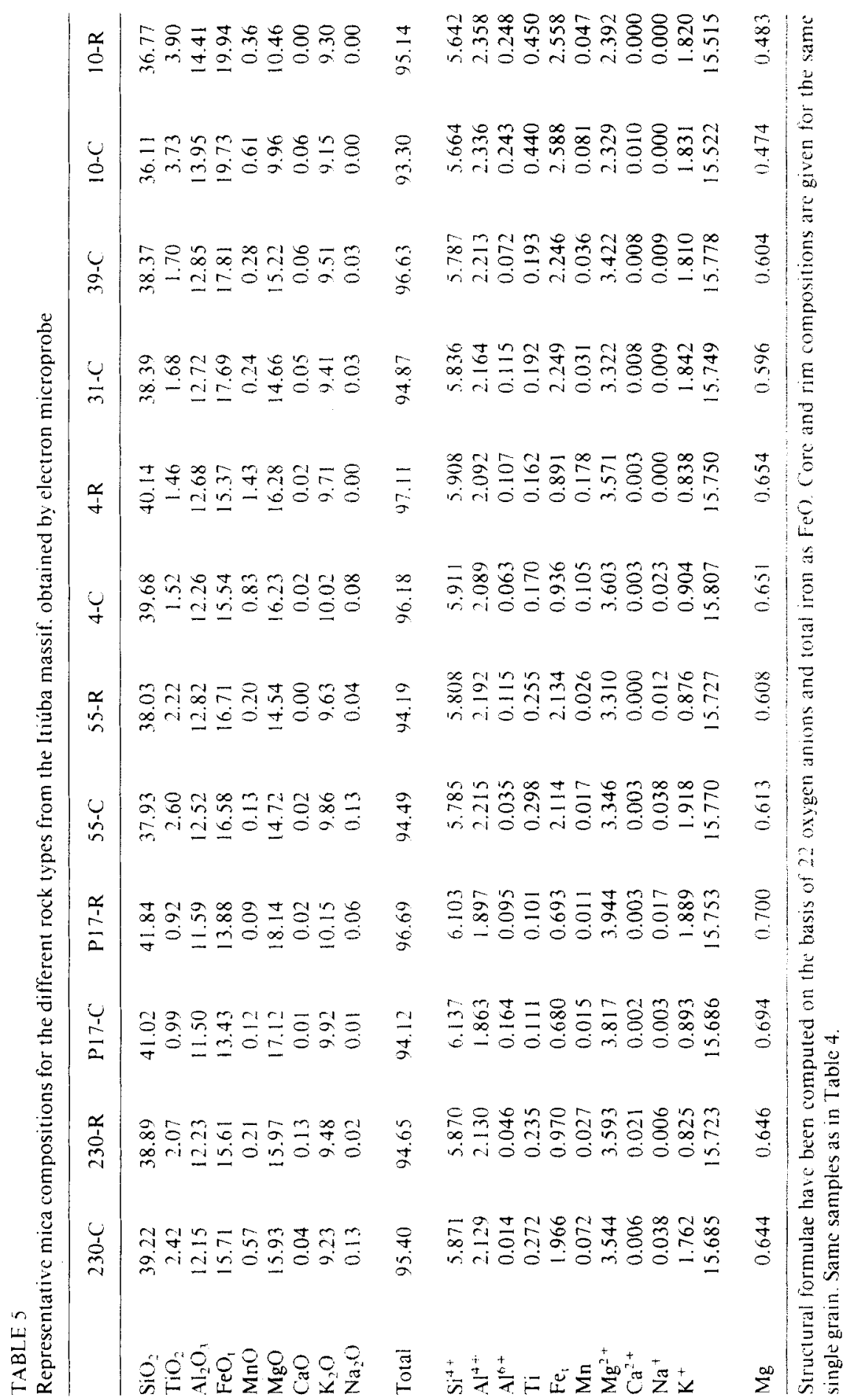


tion from edenite to $\mathrm{Mg}$-hastingsitic hornblende is marked by decreasing Si and alkali contents and increasing $\mathrm{Ca}+\mathrm{Al}(\mathrm{IV})$, and $\mathrm{Ti}$ contents, and increasing Fe-oxidation state. This trend, in contrast to the general differentiation trend, reflects the fact that, in the dykes, amphiboles crystallized directly from a liquid at an early stage, and not from the breakdown of clinopyroxene.

Helz (1973) and Spear (1981) have shown that Ti-poor amphiboles crystallize under conditions between NNO and HM buffers. We infer that the Ti-poor amphiboles of the Itiúba massif have crystallized under oxidizing conditions. Experimental data for edenite (Greenwood, 1979) show that a quartz+ albite + tremolite assemblage is stable at temperatures between 400 and $500^{\circ} \mathrm{C}$, and that edenitic amphibole is stable at higher temperatures, below $1000^{\circ} \mathrm{C}$. However, stability limits are influenced by $\mathrm{XCO}_{2}$ in the fluid phase (Widmark, 1974), resulting in a large range of stability for the edenite + calcite assemblage. In the Itiúba massif, calcite is present as a late-stage product of amphibole breakdown. These results indicate that amphiboles of groups I and II have crystallized at temperatures lower than $1000^{\circ} \mathrm{C}$, and place the transition from amphiboles of groups I and II to amphiboles of group II at about $500^{\circ} \mathrm{C}$, i.e. at the subsolidus stage.

\section{Mica}

In mafic enclaves as well as in hypersolvus syenite facies, mica is late, and always crystallizes after amphibole, whereas in dykes, mica can crystallize earlier than amphibole.

Representative analyses are listed in Table 5. Compositions range from phlogopite (11$28 \%$ of annite molecule) to biotite (34-36\% of annite molecule) (Fig. 6). According to Robert (1976a, b), Le Bel (1979), and Kurepin (1988), low Al(IV)-and Ti-contents correlate with low temperatures of crystallization. $\mathrm{Ti}$ contents are even lower than plutonic values

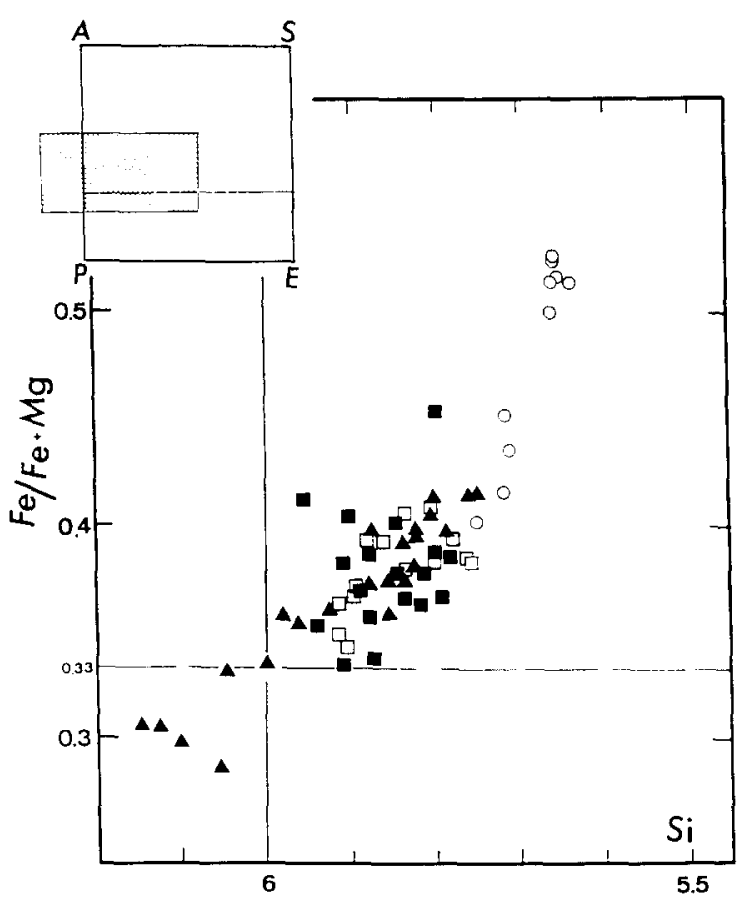

Fig. 6. Mica compositions expressed as $\mathrm{Fe} / \mathrm{Fe}+\mathrm{Mg}$ vs. Si. The shaded area represents the compositions of analysed crystals for the whole range of rock types. End-members: $A=$ annite; $S=$ siderophyllite; $P=$ phlogopite; $E=$ eastonite. Same symbols as in Fig. 4.

given by Robert (1976b). The $m g$-ratio $\left(m g=\mathrm{Mg} / \mathrm{Mg}+\mathrm{Fe}_{\mathrm{t}}\right)$ decreases from mafic enclaves $(0.70-0.65)$, mafic layers $(0.61)$, and syenite $(0.60)$ to dykes $(0.48-0.47)$, its evolution being parallel to amphibole $m g$-ratio evolution.

Anomalously Si-rich phlogopites occur in one mafic enclave (P17, Table 5) with Si ranging from 6.10 to 6.14 in the structural formulae. The same feature has been described previously in metasomatic phlogopites (Seifert and Schreyer, 1971; Guidotti, 1984) and in potassic silica-undersaturated association (Seifert and Schreyer, 1971; Hazen et al., 1981; Wagner et al., 1987). Seifert and Schreyer (1971) explained the Si-enrichment by the substitution scheme: $\mathrm{Mg}+2 \mathrm{Al}(\mathrm{IV}) \rightleftharpoons 2 \mathrm{Si}+$ vacant site.

Temperatures of about $600^{\circ} \mathrm{C}$ are estimated from experimental oxygen fugacity and $m g$-ra- 


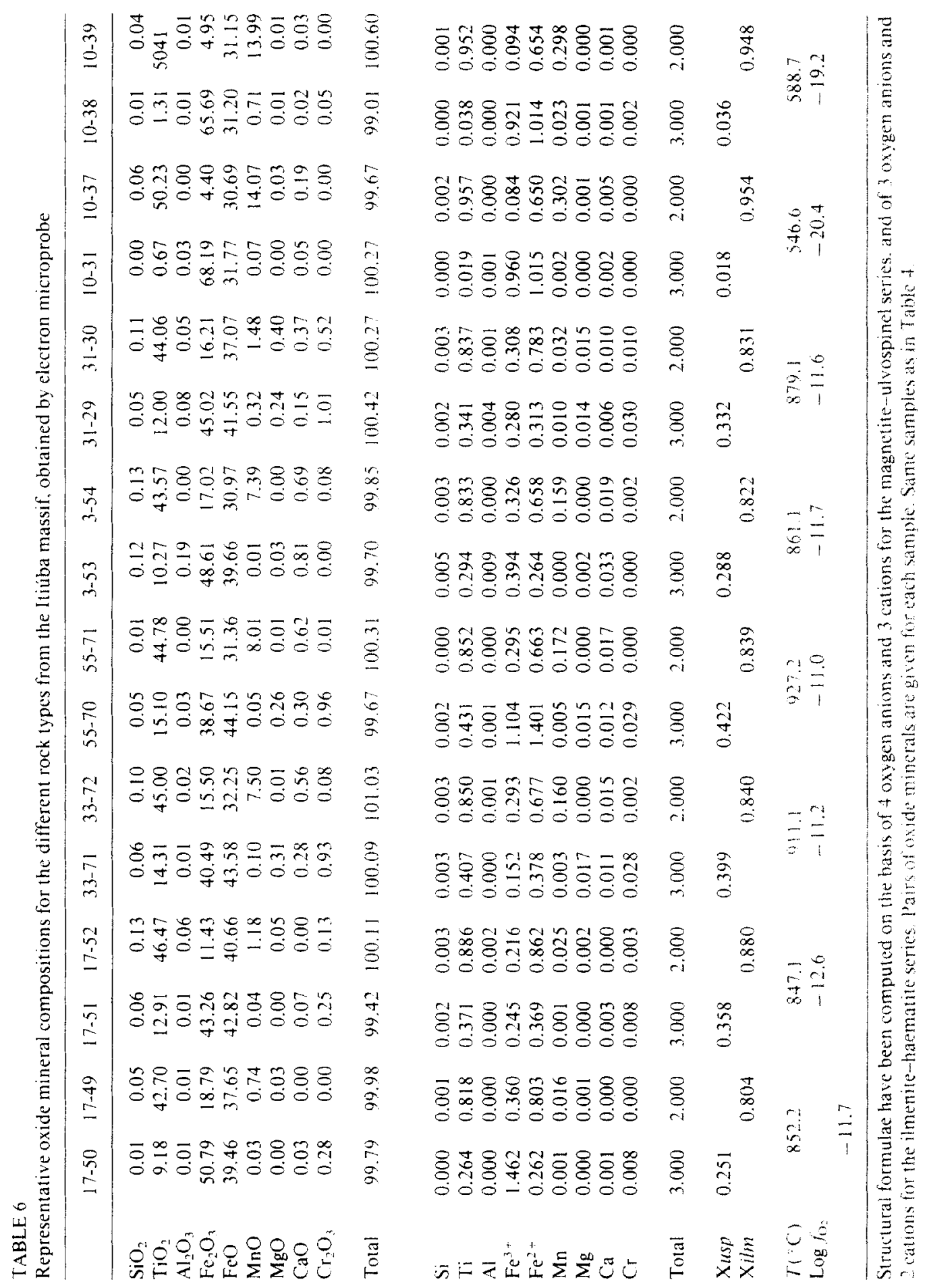


tio data (Wones and Eugster, 1965) and approximate to temperatures calculated for clinopyroxene reequilibration.

\section{$\mathrm{Fe}$-Ti oxides}

The oxide minerals ilmenite and Ti-magnetite are present throughout the massif. Representative analyses are listed in Table 6. Fresh crystals having preserved their original compositions are included within alkali feldspar crystals (mafic layer, samples 33,55 ; syenite, sample 31). The others are interstitial and reequilibrated at lower temperatures under more oxidizing conditions. Accordingly, they are always rimmed by titanite, sometimes converted into leucoxene and rutile.

Temperatures have been obtained using the geothermometer of Spencer and Lindsley (1981). In fresh crystals, enclosed by alkali feldspars, oxide pairs formed by exsolution within a single grain yield NNO buffering con-

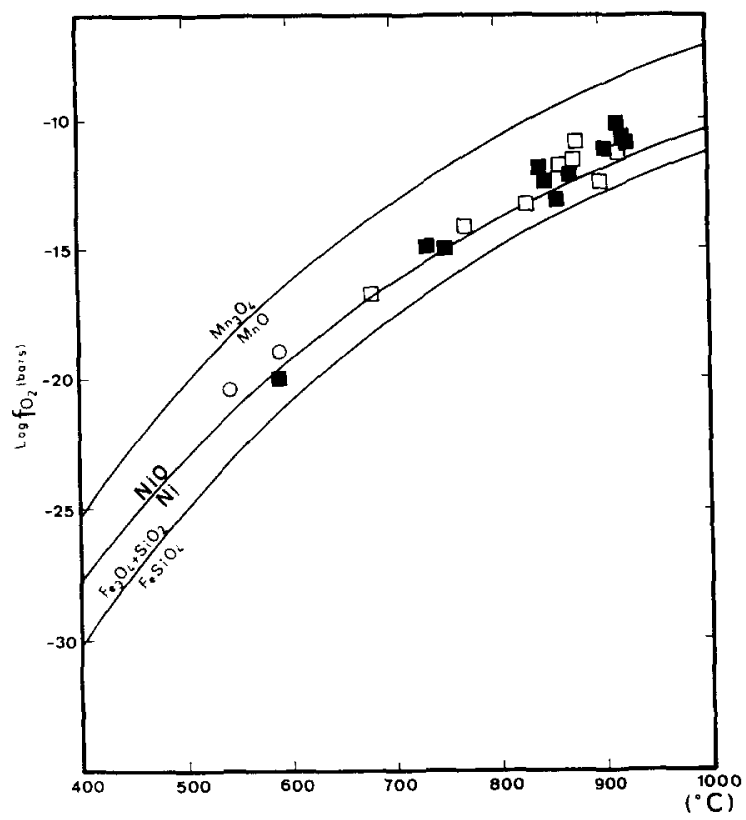

Fig. 7. Oxide mineral compositions plotted on $f_{\mathrm{O}_{2}}$ vs. temperature diagram. Same symbols as in Fig. 4. Representative buffers are indicated. Pairs enclosed within alkali feldspars yield the highest temperatures, other pairs were analysed outside of alkali-feldspar crystals. ditions for oxygen fugacity, and temperatures between 880 and $930^{\circ} \mathrm{C}$, which are compatible with the hypersolvus conditions estimated for alkali feldspar. Lower temperatures (from 860 to $300^{\circ} \mathrm{C}$ ) calculated for some oxide pairs do not significantly differ from clinopyroxene and alkali feldspar reequilibration temperatures. In these cases, oxygen fugacity is higher than for those controlled by NNO buffer (Fig. 7).

Thus, it was impossible to determine the crystallization temperature for the oxide minerals, which must have nevertheless been higher than $900^{\circ} \mathrm{C}$ (exsolution process within single grains). However, oxide mineral compositions emphasize the large range of temperatures of subsolidus reequilibration processes, which have affected also major mineral components, under fairly oxidizing conditions.

\section{Thermal constraints}

Present alkali feldspar compositions are the result of a complex magmatic crystallization history and reequilibration effects during cooling of the pluton. Therefore, it is not possible to use the chemical data (Tables $I$ and 2) as constraints for liquidus and/or solidus temperature determinations. If an equilibrium state is assumed for $\mathrm{K}$ - and Na-rich pairs, the chemical data should record cooling effects from liquidus to subsolidus stages. For almost pure alkali feldspars, experimental data in the system $\left[\mathrm{Na} \mathrm{Al} \mathrm{Si}{ }_{3} \mathrm{O}_{8}\right]-\left[\mathrm{K} \mathrm{Al} \mathrm{Si}_{3} \mathrm{O}_{8}\right]$ at various water pressures (e.g. Martin and Bonin, 1976; Martin, 1988) can provide some insights into the cooling history.

From mafic layers to syenites, bulk alkali feldspar compositions range from $\mathrm{Or}_{70}$ to $\mathrm{Or}_{63}$, which could represent evolving compositions of alkali feldspars crystallizing from a magma between liquidus and solidus, which were extracted from the residual liquids at temperatures above the solvus crest, i.e. $720^{\circ} \mathrm{C}$ at $5 \mathrm{~kb}$ water pressure. In pegmatite dykes, bulk compositions evolving from $\mathrm{Or}_{61}$ to $\mathrm{Or}_{78}$ reflect cooling temperatures from 680 to $540^{\circ} \mathrm{C}$ in the 


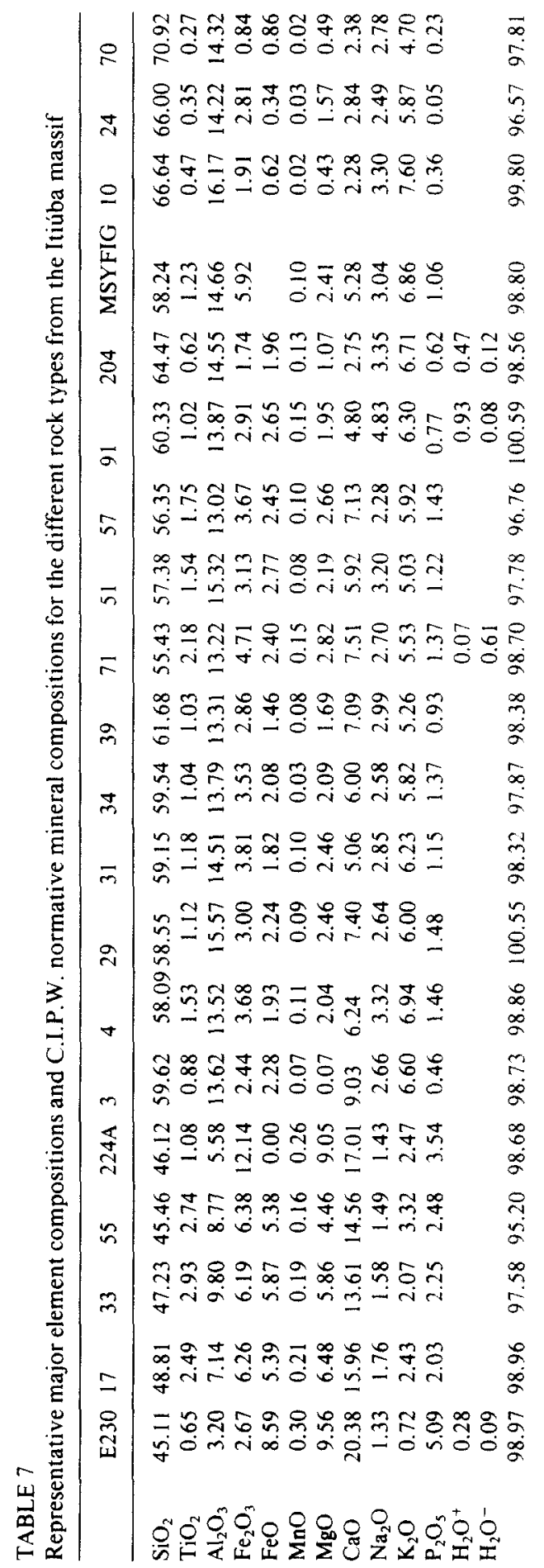

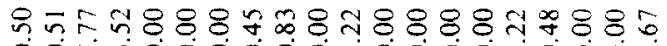
००

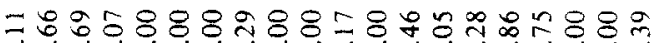

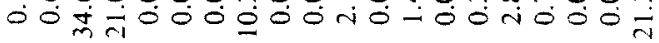

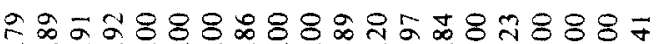

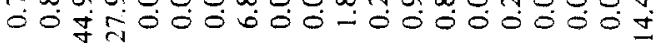

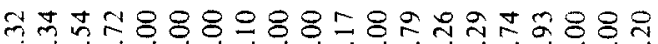

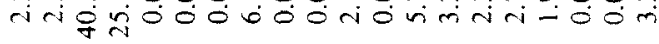

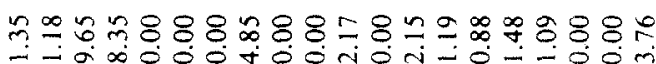
- -

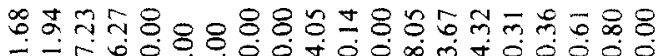

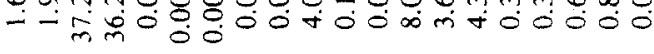

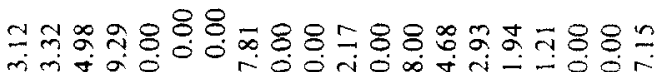

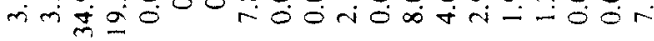

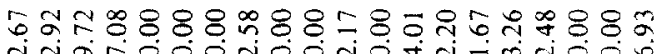

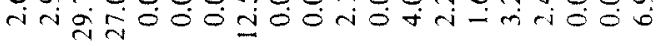
g士 तi

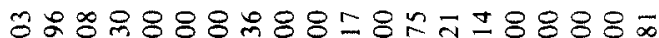

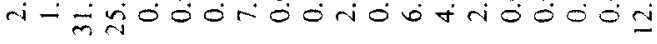
일.

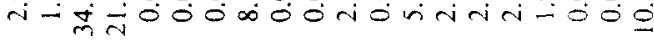

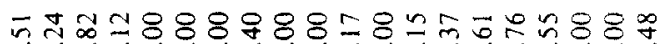
inimino

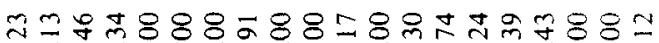

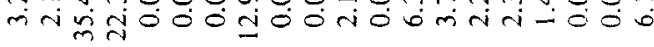

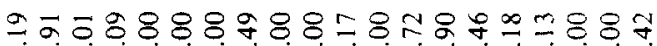

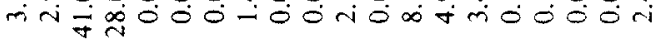

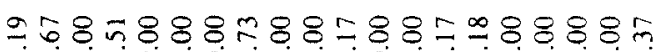
m- बiñ

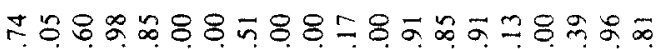

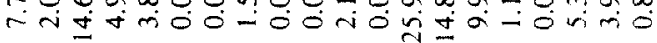

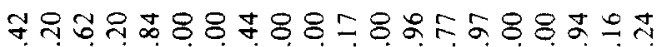

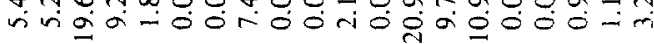
그뉴ำ

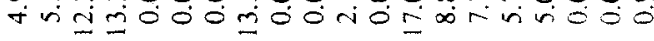

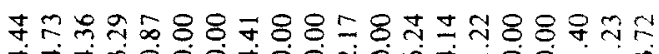

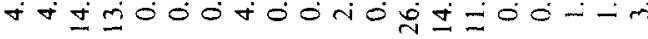
Nํำ Z-

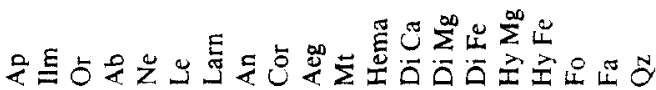

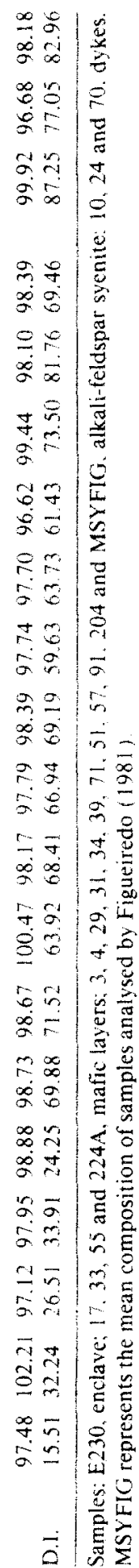




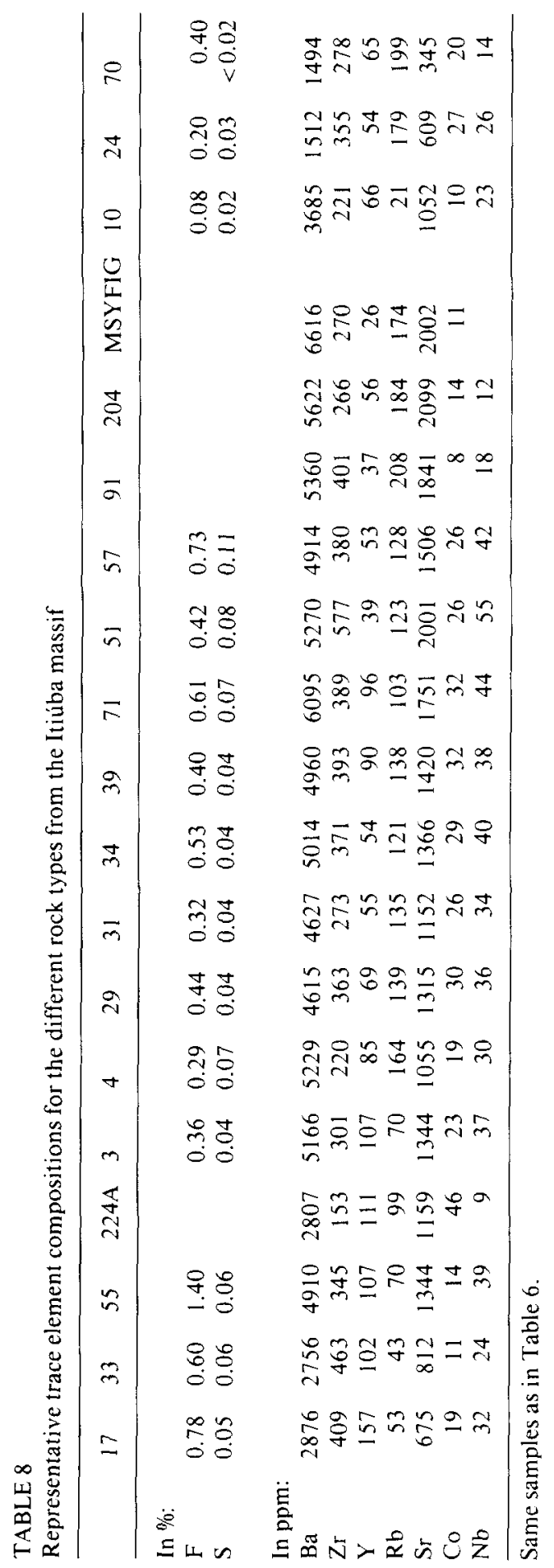



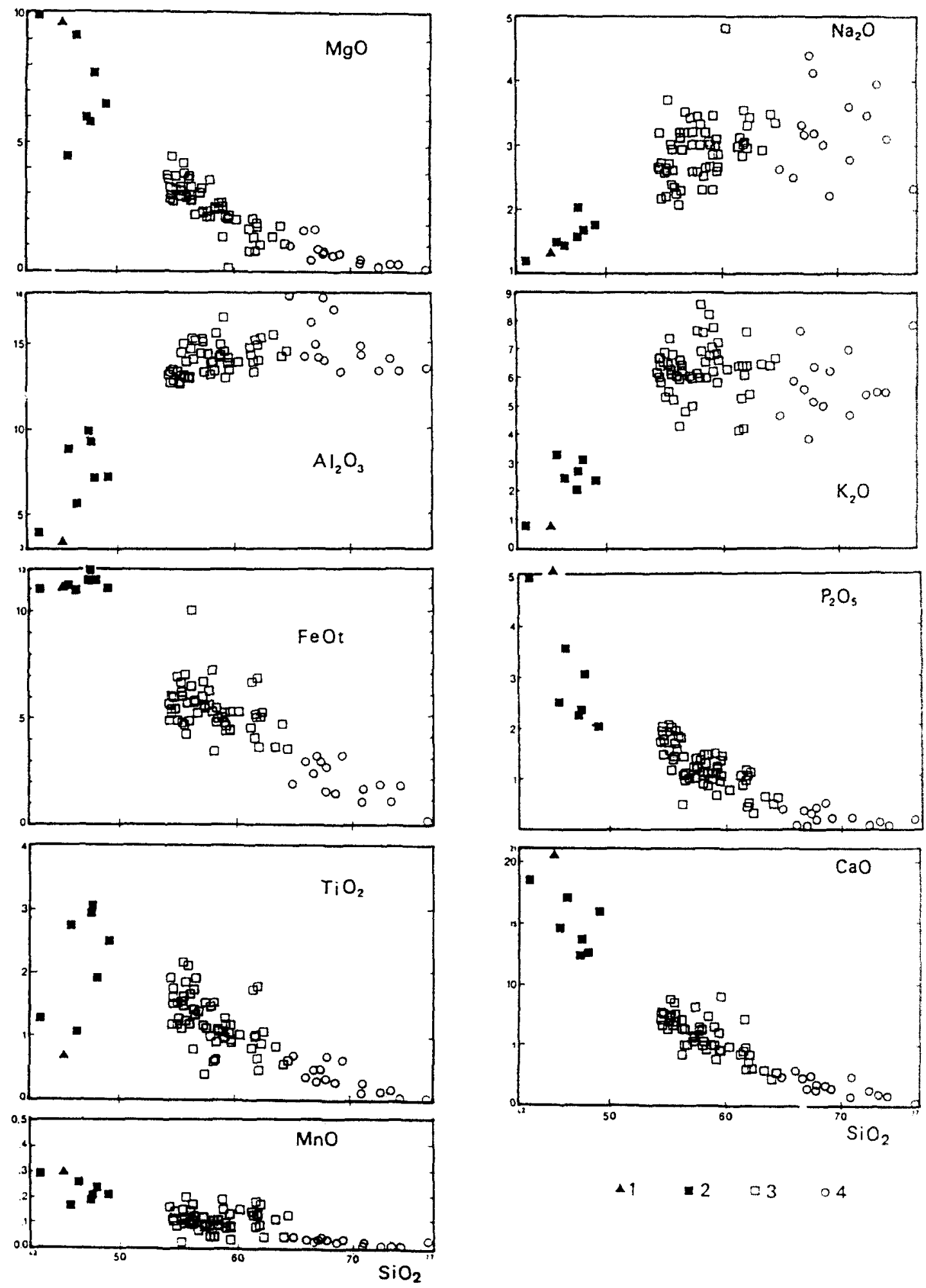

Fig. 8. Harker diagrams. Same symbols as in Fig. 4. Data from Table 7. 
field of sanidine-orthoclase solid solutions.

On the other hand, chemical analyses of the two discrete phases present within single crystals provide evidences that alkali feldspar crystals have experienced strong cooling effects, with pure albite and $\mathrm{K}$-rich phase ranging from $\mathrm{Or}_{74}$ to $\mathrm{Or}_{96}$, corresponding to temperatures decreasing from 580 to less than $300^{\circ} \mathrm{C}$, in the microcline field.

Careful examination of chemical compositions of the other rock-forming minerals leads to the conclusion that it is unlikely that thermometric determinations using classical geothermometers can provide liquidus and/or solidus temperatures. In fact, the thermodynamical parameters computed here emphasize instead the cooling history of the different liquids. Two stages are evident: a magmatic to post-magmatic stage with temperatures higher than $720^{\circ} \mathrm{C}$, and a subsolidus stage coinciding with a fall in temperature to below $300^{\circ} \mathrm{C}$.

Alkali feldspar and $\mathrm{Fe}-\mathrm{Ti}$ oxide mineral compositions indicate crystallization temperatures up to $900-950^{\circ} \mathrm{C}$ and subsolidus reequilibrations down to $300^{\circ} \mathrm{C}$. Clinopyroxene, amphibole and mica suggest closure of their mineral systems below the solidus at about $600-700^{\circ} \mathrm{C}$. In every case, oxygen fugacity is at or higher than NNO buffering conditions.

\section{Major and trace element chemical data}

Carefully collected samples of the different rock types have been analyzed by the atomic absorption method at the Federal University of Bahia (UFBA, Salvador, Bahia, Brazil), by XRF techniques at the Laboratoire de Pétrographie-Volcanologie, Université Paris-Sud, Orsay, and the Institut de Géologie, Université de Rennes (both in France). A representative set of data is listed in Tables 7 and 8 .

Major element data have been plotted on Harker diagrams (Fig. 8). The different rock types are well defined by their respective $\mathrm{SiO}_{2}$ contents: mafic layers and enclaves (42.8- $\left.48.8 \% \mathrm{SiO}_{2}\right)$, syenite $\left(54.95-64.6 \% \mathrm{SiO}_{2}\right)$ and dykes (66-76.4\% $\left.\mathrm{SiO}_{2}\right)$.

Harker plots (Fig. 8) and trace element vs. $\mathrm{SiO}_{2}$ plots (Fig. 11 ) indicate that the different rock types belong to a single suite evolving under fractional crystallization processes. In this scheme, cumulative rock types are represented by mafic enclaves, as exemplified by their major and trace element behaviour. They contrast with mafic layers and syenite, in which $\mathrm{Sr}, \mathrm{Ba}, \mathrm{Y}$ and Co plots are characterized by an overall decrease with increasing silica, combined with a network of small-scale parallel trends showing a positive correlation. This complex feature is interpreted as reflecting varying accumulation rates of alkali feldspar, apatite, clinopyroxene and oxide minerals, as well as liquid compositional evolution. Thus, mafic layers and syenite are considered as representing various mixtures of cumulates + residual liquids, formed through mechanical mixing during magmatic stages. Dykes consist of rocks resulting from the crystallization of residual liquids, derived by filter-pressing.

Bimodal compositional features in alkaline rocks are well-known from basalt-trachyte volcanic suites (Upton, 1974). However, in the case of Itiúba, the bimodal characteristics correspond to an association of cumulative mafic

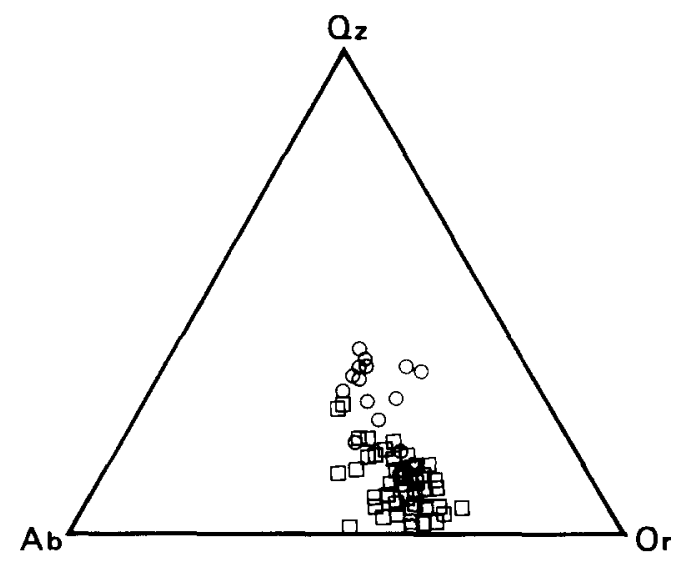

Fig. 9. Alkali-feldspar syenite and dyke compositions expressed as C.I.P.W. normative Qz-Ab-Or. Samples with DI higher than 60 have been plotted, expanding upon the original suggestion of DI 80 by Tuttle and Bowen (1958). 
types and of residual liquid crystallization products. The major rock-type resulting from the mixing of cumulates and residual liquids is an alkali-feldspar syenite, displaying a mildly alkaline, metaluminous, Si-saturated chemistry. One exceptional sample yields a peralkaline composition (sample 91).

Quartz, albite and orthoclase are the chief normative mineral components. The Differentiation Index (Thornton and Tuttle, 1960) ranges from 59.6 to $81.7 \mathrm{wt} \%$ (Table 7 ), corresponding to mildly to highly evolved compositions. In almost all samples, normative anorthite is weak, and almost all available $\mathrm{Ca}$ is used for normative apatite and clinopyroxene calculation. This results in a close relationship between modal and normative mineral compositions.

In the classic $\mathrm{Qz}-\mathrm{Ab}-\mathrm{Or}$ system (Tuttle and Bowen, 1958), irrespective of the water vapour pressure, the alkali-feldspar syenites, characterized by high $\mathrm{K}_{2} \mathrm{O}$ contents (about 5 wt $\%$ ) and high $\mathrm{K}_{2} \mathrm{O} / \mathrm{Na}_{2} \mathrm{O}$ ratios (from 1.5 to 3.0 ), lie in the primary field of K-rich alkali feldspar, and not in the thermal valley in which evolving residual liquids are generally located (Fig. 9). According to experimental data on the haplogranitic system, the Itiúba alkali-feldspar syenites cannot be crystallization products of residual (equilibrium) melts, but most probably represent the solid residuum of a solid-melt system from which "minimum-type" liquids,

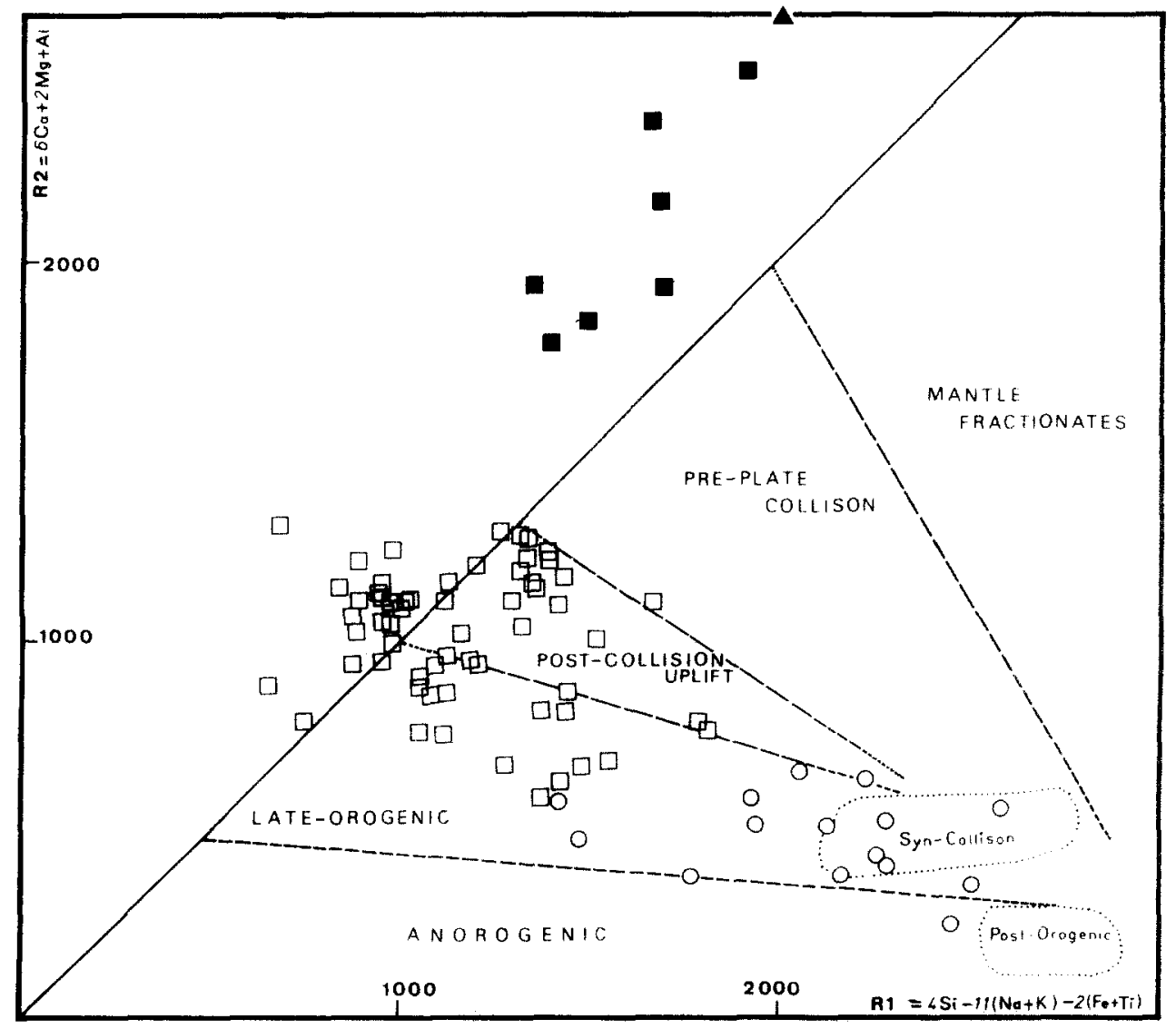

Fig. 10. R1-R2 multicationic diagram. Same symbols as in Fig. 4. Fields of mantle fractionates, pre-plate collision, postcollision uplift, late-orogenic, anorogenic, syn-collision and post-orogenic granite associations are from Batchelor and Bowden (1985). 

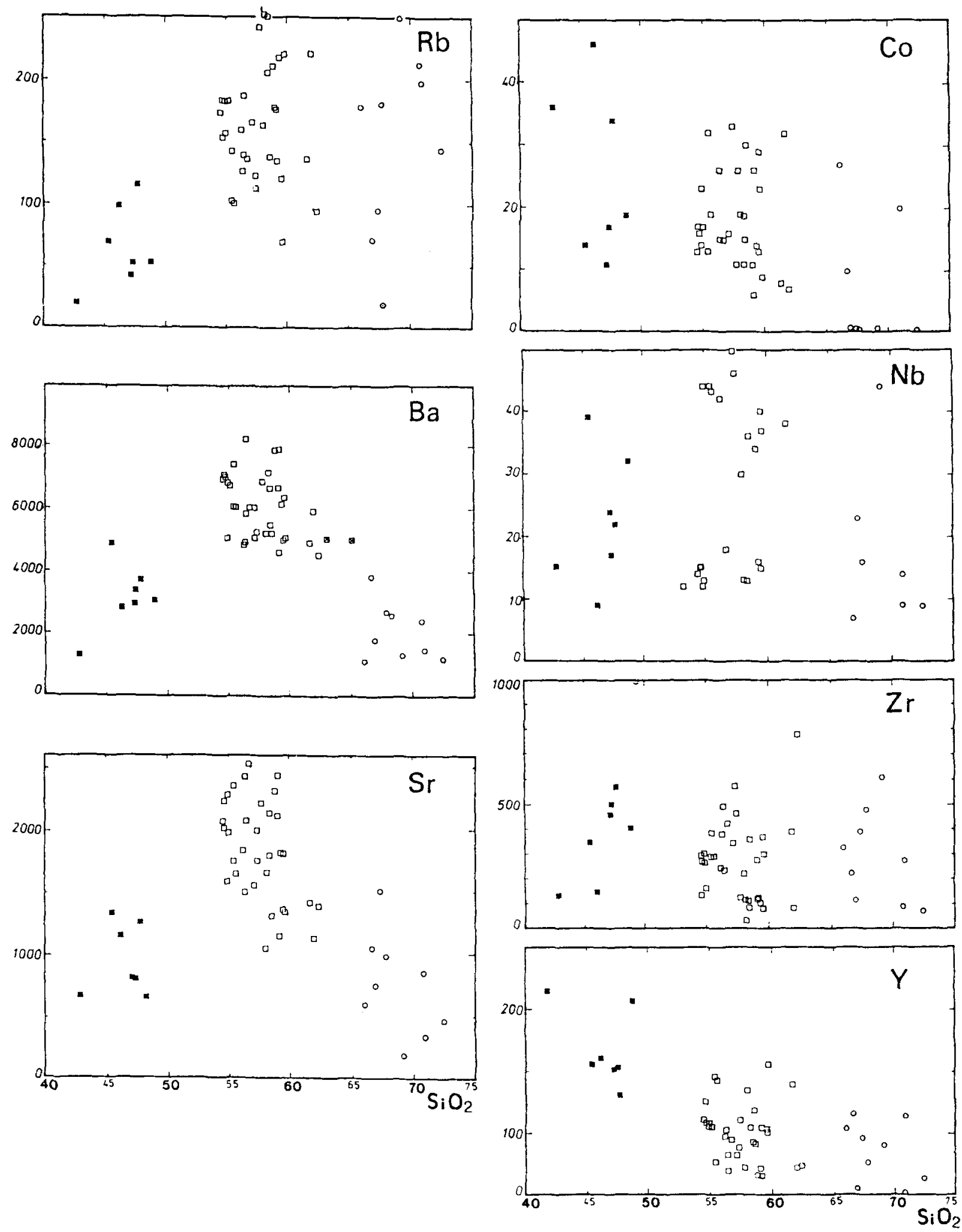

Fig. 1 1. Trace elements vs. $\mathrm{SiO}_{2}$ diagrams. Same symbols as in Fig. 4. 


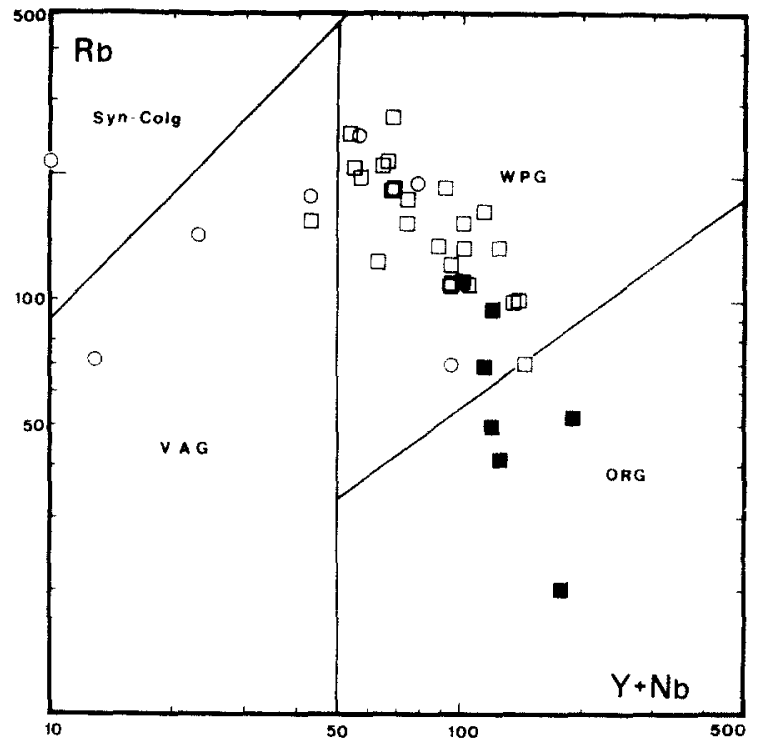

Fig. 12. Rb vs. $\mathrm{Y}+\mathrm{Nb}$ diagram (Pearce et al., 1984). Same symbols as in Fig. 4. Note that alkali-feldspar syenites plot in the whithin-plate granite ( $W P G$ ) field, while mafic layers straddle the WPG field and the oceanic ridge granite $(O R G)$ field, and dykes are scattered throughout the WPG field, the syn-collision granite (Syn-Colg) field and the volcanic arc granite $(V A G)$ field.

with compositions lying in the thermal valley, were extracted by filter-pressing.

The late-stage dykes display nearly identical features: highly evolved and metaluminous to slightly peraluminous compositions, with D.I. ranging from 77 to $87 \mathrm{wt} \%$, and plot in the primary field of alkali feldspar and/or along the quartz-alkali feldspar cotectic line in the normative $\mathrm{Qz}-\mathrm{Ab}$-Or diagram.

In multicationic diagrams (de la Roche et al., 1980), the entire magmatic suite plots in the late-orogenic granitoid field, designated by Batchelor and Bowden (1985) (Fig. 10).

Trace elements (Table 8 , Fig. 11 ) show very complex patterns, due to the mixing of both cumulation and differentiation processes. Some elements, such as $\mathrm{Ba}$ and $\mathrm{Sr}$, exhibit incompatible behaviour when progressing from mafic enclaves and layers to alkali-feldspar syenites, and then a compatible behaviour from alkali-feldspar syenites to late-stage dykes, illustrating the role played at an intermediate stage by alkali feldspar fractionation. The compatible behaviour of $\mathrm{Y}$ throughout the range of samples, from mafic enclaves and layers through syenites to late-stage dykes, is consistent with apatite being an early fractionating mineral. On the other hand, Rb seems to behave as an incompatible element throughout the suite, with the exception of some dykes of the Na-rich subsolvus trend.

Other trace elements, such as $\mathrm{Nb}$ and $\mathrm{Zr}$, do not follow any specific trend. However, this group is characterized by rather strong enrichments, so that in Fig. 12, almost all analyzed samples, even the mafic ones, lie in the withinplate granite field. The cause of such erratic variations probably lies in the role played by accessory minerals, such as apatite ( $\mathrm{Sr}, \mathrm{Y}$ ), oxide minerals $(\mathrm{Nb})$, titanite $(\mathrm{Y})$, and zircon $(\mathrm{Zr}, \mathrm{Y})$, which acted as early fractionating minerals and can constitute a significant portion of the cumulates. This results in a decoupling between major elements, controlled by clinopyroxene and alkali feldspar fractionation, and trace elements, controlled mainly by accessory minerals.

Rare earth elements (Table 9 and Fig. 13) display strong enrichments in LREE and depletions in HREE (normalized $\mathrm{La} / \mathrm{Yb}$ ratio of 58.5 for mafic layers, and 40.5 for syenite ), reflecting a strongly fractionated magma. No Eu-

TABLE 9

Rare earth elements compositions for a mafic layer (sample 224A) and for average alkali-feldspar syenite (MSYFIG, Figueireido, 1981)

\begin{tabular}{lllllllllll}
\hline & La & Ce & Nd & Sm & Eu & Gd & Dy & Er & Yb & Lu \\
\hline 224A & 526.91 & 996.41 & 452.83 & 74.57 & 13.91 & 47.33 & 22.22 & 8.53 & 5.95 & 0.94 \\
MSYFIG & 159.3 & 327.0 & 168.2 & 30.9 & 8.8 & 21.8 & 9.4 & 3.1 & 2.6 & \\
\hline
\end{tabular}




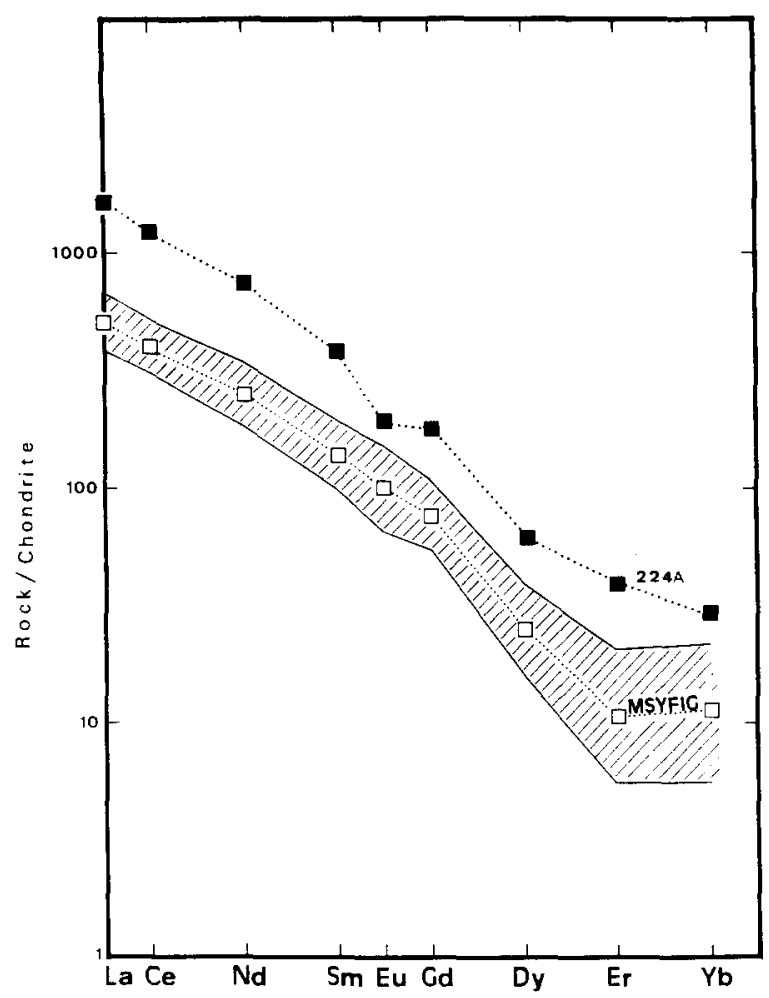

Fig. 13. Chondrite-normalized REE patterns for a mafic layer (224A) and average alkali-feldspar syenite (hatched area and sample $M S Y F I G$ ). $\mathrm{C} 1$ chondrite has been used as the source for chondrite values. Same symbols as in Fig. 4.

anomaly is present, implying that plagioclase played no obvious role in the fractionation scheme. Comparison of REE patterns of alkali-feldspar syenites (Figueiredo, 1976, 1981) and of REE-enriched mafic layers (sample 224 ) indicates that at this stage, the distribution coefficient between solid and liquid for all REE was nearly constant and exceeded 1.0.

\section{Discussion and comparison with rapakivi magmatic complexes}

Geological, mineralogical and geochemical data indicate that rocks constituting the Itiúba massif cannot represent magmatic liquids. It is deduced instead that the major alkali-feldspar syenite consists of light mineral cumulates, having crystallized from a syenitic/granitic liquid. Evidence for this interpretation is:

(1) The different rock types have been emplaced as a crystal mush, as exemplified by layered and flow structures and the superimposing of a foliation before the emplacement of the late-stage dykes.

(2) They are made up of alkali feldspar, clinopyroxene, oxide minerals and apatite, which were converted to a microcline, albite, amphibole, biotite and titanite assemblage by subsolidus reequilibration.

(3) The leucocratic rocks plot in the primary field of alkali feldspar in the normative Qz-Ab-Or diagram, on the Or-side of the thermal valley. The late dykes lie on the quartzalkali feldspar cotectic line.

(4) Ti and P contents are higher than expected for syenitic liquids, and indicate apatite + oxide cumulation processes, either by gravitational settling, or by removal of residual liquids by filter-pressing.

(5) $\mathrm{Ti}, \mathrm{P}$ and trace element contents are controlled by accessory minerals and display complex patterns with an overall identical behaviour and small-scale reverse behaviours. These features can be explained by mixing cumulate minerals with continuously evolving residual liquids.

(6) Thermometric data are compatible with initial magmatic crystallization around $930^{\circ} \mathrm{C}$ and subsolidus reequilibration down to $300^{\circ} \mathrm{C}$, with a maximum around $600^{\circ} \mathrm{C}$.

If this interpretation is correct, it implies that the alkali-feldspar cumulates cannot be formed from less evolved magmas, as plagioclase is totally absent as a discrete phase and, according to REE data (absence of Eu-anomaly), was never a liquidus phase; anorthosite is also completely lacking. Therefore, we favour a somewhat evolved liquid with co-precipitating apatite and clinopyroxene, followed by alkali feldspar as a single hypersolvus phase. Such a liquid can yield syenitic or granitic compositions. However, it is difficult at present to calculate the composition of the liquid filling the reservoir. 
Numerous examples throughout the world substantiate the intermediate nature of the liquids replenishing deep alkaline magma chambers (Bonin and Giret, 1985; Duchesne and Hertogen, 1988 ), and yielding monzonoritic to monzonitic compositions. These liquids evolve towards felsic compositions through clinopyroxene and amphibole fractionation processes (Maury et al., 1980; Giret et al., 1980).

At a very late stage, as a result of their buoyancy, residual liquids with syenitic or granitic compositions are collected at the top of the magma chamber. We propose that cooling of the top of the magma chamber results in crystallization and accumulation of alkali-feldspar syenites, coupled with the extraction of highly evolved alkaline granite liquids which are subsequently emplaced at shallow levels, such as in caldera volcanoes and associated ringcomplexes.

The Itiúba massif provides a very good example, since the top of the magma chamber was filled up during only one single episode. No evidence of replenishing has so far been found. Other occurrences of similar alkali-feldspar syenites have been described in Bahia State, and in other places in Brazil as well: preliminary examinations of samples from these other massifs display identical features and we interpret them, therefore, as further examples of syenitic-granitic magma chamber roof.

In other cases, which may represent the majority, refilling of a solidified magma chamber would result in the disruption of early alkalifeldspar syenite roof cumulates. Thus, new liquids filling up the magma chamber would be enriched in alkali feldspar xenocrysts, coming from the walls and the roof. According to the new liquid compositions, feldspar crystals would behave in several contrasting ways:

(1) In new liquids with intermediate compositions (e.g. monzonitic, monzonoritic), unstable alkali feldspar would become partially resorbed and crystals would then display rounded shapes. During cooling, plagioclase crystallizing from the liquid can constitute a rim growing epitaxically on the alkali feldspar rounded core.

(2) In more evolved liquids (e.g. syenitic), resorption of alkali feldspar could take place at a small scale. During cooling, little or no plagioclase can crystallize as a discrete phase, and hence only new alkali feldspar can be produced as a rim around the old alkali feldspar rounded core.

(3) In highly evolved liquids (e.g. granitic), early alkali feldspar remains stable and can form euhedral crystals. After cooling and complete solidification, two generations of euhedral alkali feldspars can be observed.

However, these features are to be expected mainly at the magma chamber level. During the ascent of the liquids to the surface, large alkalifeldspar crystals are carried only if the ascent velocity is sufficiently high. In general, liquids filling up ring-complexes are devoid of early crystals because of their low density, which is related to the presence of F-rich fluids and/or fluid vesiculation. In the case of volcanic formations, some examples of the sanidine-bearing basalt-trachyte association have been documented, e.g. the Sancy volcano in the MontDore caldera (Brousse, 1961; Julien, 1988).

We suggest that the rapakivi magmatic association, as defined in Finland (Vorma, 1976; Haapala, 1988), may provide a good example of a reworked magma chamber. With the exception of cumulative anorthosites and leucogabbros, and of relatively uncommon evengrained rock types, such as tirillite and Lappee granite, the major rock types (Vorma, 1976; Haapala, 1988) are characterized by large generally rounded crystals of pink to red alkali feldspar and black quartz. Wiborgite with ovoid crystals made up of pink alkali feldspar rimmed by green albite-oligoclase, pyterlite with rimless ovoid crystals of pink to red alkali feldspar, and porphyritic rapakivi granite could respectively represent the three types of alkali feldspar-liquid relations described above. The fact that, in one exposure, the three types of rapakivi alkali feldspar textures can be ob- 


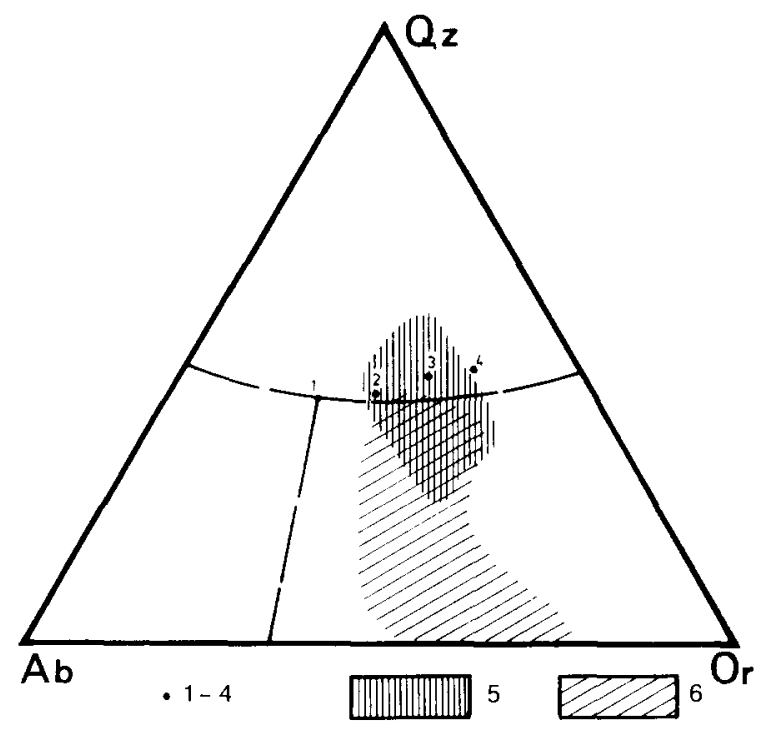

Fig. 14. C.I.P.W. normative Qz-Ab-Or diagram. Points labelled $I$ to 4 correspond to minimum melt compositions of varying $\mathrm{Ab} / \mathrm{An}$ ratios, according to von Platen (1965) and Winkler (1967): $l=\mathrm{Ab} / \mathrm{An}=7.8 ; 2=5.2$; $3=3.8 ; 4=1.6 ; 5=$ area of the Finish rapakivi magmatic association (Vorma, 1976); $6=$ field for Itiúba alkalifeldspar syenites. Quartz-alkali feldspar cotectic line and alkali feldspar thermal valley for $\mathrm{PH}_{2} \mathrm{O}-2 \mathrm{kbar}$ (Tuttle and Bowen, 1958 ) are also indicated.

served together, is a supplementary argument.

In the Wiborg, Laitila, and Ahvenisto rapakivi massifs of SW and SE Finland (Vorma, 1976; Haapala, 1988), the areal distribution of wiborgite, pyterlite and rapakivi granite supports the idea that the liquids filling up the magma chamber probably yielded intermediate compositions and subsequently evolved to granitic compositions. Early even-grained types such as tirillite could represent original liquids. In this scheme, all rapakivi rock types were produced by the disruption of early alkali feldspar (plus quartz) cumulates by evolving monzonitic to granitic liquids. This interpretation is supported by plots of rapakivi magmatic rocks in the normative $\mathrm{Qz}-\mathrm{Ab}-\mathrm{Or}$ diagram, which exactly lie on the same area as some rocks from the Itiúba massif (Fig. 14).

\section{Conclusion}

The Proterozoic alkaline syenite massif of Itiúba (Bahia, Brazil) provides a unique example of the top of a crystallized magma chamber:

(1) Magmas were emplaced at intermediate depths between the lower and upper crust.

(2) Textures and structures of the rock provide evidence for strike-slip movements accompanied by small-scale shearing effects along a major lithospheric fault and document latestage magmatic processes related to deformation and the synchronous emplacement of dykes.

(3) Roof accumulation of crystals from highly differentiated silicate liquids is indicated by early precipitation of apatite and oxide minerals, together with clinopyroxene and alkali feldspar as an hypersolvus single phase.

(4) Crystallization of anhydrous minerals resulted in the build-up of volatiles and in the subsolidus conversion of the primary magmatic assemblage into a hydrous and low-temperature assemblage.

Subsequent refilling of the magma chamber can promote disruption of the older cumulates by the younger liquids. We suggest that the famous rapakivi magmatic association could represent modified roof cumulates by the incorporation and assimilation of early alkali feldspar + quartz within new liquids. These new liquids range from monzonitic to granitic compositions, and are produced by the differentiation of a monzonitic original liquid, inside the magma chamber. Different kinds of reaction relationships between liquids and early crystals would result in distinct rock types, yielding special textures, such as wiborgitic, pyterlitic and porphyritic.

In this case, neither magma mixing events, nor metasomatic subsolidus recrystallizations, as frequently proposed for this type of association (for a review, see Vorma, 1976; Haapala, 1988 ), are required. Rounded alkali feldspar and quartz crystals are thus interpreted as xen- 
ocrystic within alkaline magmas belonging to the same suite.

\section{Acknowledgements}

This paper has benefitted from fruitful discussions with the late J. Lameyre (Paris, France) and L.V. Nardi (Porto Alegre, Brazil) during his stay at Orsay. Useful comments have been provided by A.N. Sial (Recife, Brazil), G.R. Lowell and an anonymous reviewer. We have tried to do our best to follow most of their recommendations, even if we did not agree with them all.

H.C. acknowledges the Brazilian Council of Research (C.N.Pq.) for its grant No. 200205/ 86.2 which has allowed him to stay at Université Paris-Sud. This work has been supported: in Brazil, by C.N.Pq./Orstom and P.A.D.C.T.F.I.N.E.P./U.F.Ba. conventions on "Granitoids in Bahia State: geology and metallogenesis"; and in France, by I.N.S.U. program on "Dynamics and Balances of the Earth": "Crustal growth at early Archean and Archean-Proterozoic transition: the example of the São Francisco Craton, Brazil". B.B. also acknowledges financial support from C.N.Pq. and U.F.Ba. for field expenses.

\section{References}

Abbot, M.J., 1969. Petrology of Nandewar volcano. Contrib. Mineral. Petrol., 20: 115-134.

Aoki, K., 1964. Clinopyroxenes from alkaline rocks of Japan. Am. Mineral., 49: 1199-1223.

Barbosa, O. and Costa, L.A.M., 1973. Projeto Leste Tocantins-Oeste do Rio São Francisco (Letos). DNPM/ CPRM/PROSPEC S.A., $5 \mathrm{v}$.

Barker, F., Wones, D.R., Sharp, W.N. and Desborough. G.A., 1975. The Pikes Peak Bahtolith, Colorado Front Range, and model for the origin of the gabbro-anothosite-syenite-potassic granite suite. Precambrian Res., 2: 97-160.

Bastos Leal, L.R., 1986. Diques graníticos no sienito de Itiúba: relações cronológicas e análise textural na caracterisação de suas fácies. VI Sem. Est. Pesq. UFBa. Bol. Res., pp. 36-37.

Batchelor, R.A. and Bowden, P., 1985. Petrogenetic inter- pretation of granitoid rock series using multicationic parameters. Chem. Geol., 48: 43-55.

Bonin, B., 1972. Le complexe granitique subvolcanique de la région de Tolla-Cauro (Corse). Thèse 3 me cycle. Paris VI, Lab. ENS, 7, $127 \mathrm{pp}$.

Bonin, B., 1980. Les complexes acides alcalins anorogeniques continentaux: l'exemple de la Corse. Thèse Doct. d'Etat, Univ. P. et M. Curie, $756 \mathrm{pp}$

Bonin, B., 1986. Ring Complex Granites and Anorogenic Magmatism. Studies in Geology. North Oxford Academic, Oxford, $188 \mathrm{pp}$.

Bonin, B., 1988. Peralkaline granites in Corsica: some petrological and geochemical constraints. Rend. Soc. Ital. Min. Petrol., 43-2: 281-306.

Bonin, B. and Giret, A., 1985. Clinopyroxene compositional trends in oversaturated and undersaturated atkaline ring complexes. J. Afr. Earth Sci., 3: 175-183.

Bonin, B. and Platevoet, B., 1988. Interactions solide liquide-fluide et phénomènes de fénitisation dans le magmatisme alcalin de Corse: l'exemple de l'association du Vieux Pont d'Ota. Bull. Soc. Géol. Fr. IV: 571 578.

Bowden, P. and Turner, D.C.. 1974. Peralkaline and associated ring-complexes in the Nigeria-Niger province, West Africa. In: $\mathrm{H}$. Sørensen (Editor), The Alkaline Rocks. Wiley, London, pp. 330-351.

Bowden, P., Batchelor, R.A., Chappell, B.W., Didier, J. and Lameyre, J., 1984. Petrological, geochemical and source criteria for the classification of granitic rocks: a discussion. Phys. Earth Planet. Inter., 35: 1-11

Brousse, R., 1961. Minéralogie et pétrologie des roches volcaniques du Mont Dore (Auvergne). Bull. Soc. Fr. Minéreral. Cristallogr., 84: 131-186;245-259.

Celino, J.J., 1986. Caracteristicas do contato sul entre o batólito sienítico de Itiúba e o granito de Pedra Solta. $\mathrm{VI}^{\mathrm{e}}$ Sem. Est. Pesq. UFBa., Bol. Res., pp. 38-39.

Conceição, H., 1990. Pétrologie du Massif syénitique d'itiúba: Contribution à l'étude mineralogique des roches alcalines dans l'Etat de Bahia-Brésil. Thèse Doct.Sci. UPS-Centre d'Orsay, 393 pp.

Conceição, H. and Sabaté, P., 1986. O batólito de Itiuba (Bahia): um corpo sienítico singular. Bol. Res. XXXIV Congr. Bras. Geol.-SBG, Goiania, pp. 146-147.

Conceição, H., Davison, I., Fujimori, S., McReath, I. and Sabaté, P., 1987. Granitoids of the state of Bahia, Brazil. ISGAM, Ext. Abst. Salvador-Ba., pp. $71-74$.

Conceição, H., Bonin, B., Sabaté, P. and Lameyre, J.. 1989a. Le massif syénitique protérozoique (Bahia, Brésil): Contexte géologique et pétrologique. C.R. Acad. Sci., Paris, 308, Série II, pp. 45-50.

Conceição, H., Sabaté, P., Domingues Alonso, M. and Bonin, B., $1989 \mathrm{~b}$. Mise en évidence d'un contrôle structural de la mise en place du massif syénitique d'âge protérozoique inférieur d'Itiúba (Bahia, Brésil). C.R. Acad. Sci. Paris, 309, Série II, pp. 403-408.

Deer, W.A., Howie, R.A. and Zussman, J., 1963. Rock- 
Forming Minerals. Chain Silicates. Longman, London. Deer, W.A., Howie, R.A. and Zussman, J., 1978. Ibid., 2nd ed, 2A. Longman, London, and Wiley, New York. de la Roche, H., Leterrier, J., Grandclaude, P. and Marchal, M., 1980. A classification of volcanic and plutonic rocks using R1-R2 diagrams and major element analyses-its relationships with current nomenclature. Chem. Geol., 29: 183-2 10.

Delgado, I. and Souza, J.D., 1975. Projeto Cobre-Curaçà: Geologia Econômica do Distrito cuprífero do Rio Curaçà-Bahia, Brasil. CPRM/DNPM, $30 \mathrm{v}$.

D'el Rey Silva, L.J.H., 1985. Geologia e controle estrutural do depósito cuprífero de Caraiba, vale do Curaçà-Bahia, Textos Básicos, SME/CPM, 6, pp. 51-123.

Didier, J., 1973. Granites and Their Enclaves: The Bearing of Enclaves on the Origin of Granites. Developments in Petrology 3, Elsevier, Amsterdam, 393 pp.

Domingues Alonso, M. and Conceição, H., 1986. Estudos dos alinhamentos do batólito de Itiúba: tratemento estatistico sobre imagens de radar-Bahia. 38 Reun. SPBPC, Curitiba, Bol. Res., 758.

Duchesne, J.-C., 1984. Massif anorthosites: another partisan review. In: W.L. Brown (Editor), Feldspars and Feldspathoids. D. Reidel, Dordrecht, pp. 411-433.

Duchesne, J.-C. and Hertogen, J., 1988. Le magma parental du lopolithe de Bjerkreim-Sokndal (Norvège méridionale). C.R. Acad. Sci. Paris, 306, Série II, pp. 4548.

Figueiredo, M.C.H. de, 1976. Geologia e geoquimica da região de Poço de Fora, Vale do rio Curaçá/Bahia. Tese de Mestrado IGUFBa-DCq., 87 pp.

Figueiredo, M.C.H. de, 1981. Geoquimica das rochas metamórficas de alto grau do nordeste da Bahia-Brasil. In: Geologia e Recursos Minerais do Estado da Bahia, Textos Básicos, SME/CPM, 4: 1-71.

Giret, A., 1983. Le plutonisme océanique intraplaque: exemple des îles Kerguelen. C.N.F.R.A., 54, 290 pp.

Giret, A., Bonin, B. and Léger, J.-M., 1980. Amphibole compositional trends in oversaturated and undersaturated alkaline plutonic ring-complexes. Can. Mineral., 18: 481-495.

Green, T.H. and Pearson, N.J., 1986. Ti-rich accessory phase saturation in hydrous mafic-felsic compositions at high P, T. Chem. Geol., 54: 185-201.

Greenwood, H.J., 1979. Thermodynamic properties of edenite. In: Current Research, Part B, Geol. Surv. Can., pp. 365-370.

Guidotti, C.V., 1984. Micas in metamorphic rocks. Rev. Mineral., 13: 357-467.

Haapala, I., 1988. Metallogeny of Proterozoic rapakivi granites of Finland. In: R.P. Taylor and D.F. Strong (Editors), Recent Advances in the Geology of Granite-Related Mineral Deposits. Spec. Vol., Can. Inst. Min. Metall., 39: 124-132.

Hasui, Y., D'el Rey Silva, L.J.H., Silva, F.J.L., Maneta, P., Moraes, J.A.C., Oliveira, J.G. and Miola, W., 1982.
Geology and copper mineralization of Curaçá river valley, Bahia. Rev. Bras. Geoc., 12: 463-474.

Hazen, R.M., Finger, L.W. and Velde, D., 1981. Crystal structure of silica- and alkali-rich trioctahedral mica. Am. Mineral., 66: 586-591.

Helz, R.T., 1973. Phase relations of basalts in their melting range at $\mathrm{P}_{\mathrm{H}_{2} \mathrm{O}}$ as a function of oxygen fugacity. $\mathrm{J}$. Petrol., 14: 249-302.

Hunter, R.M., 1987. Textural equilibrium in layered igneous rocks. In: I. Parsons (Editor) Origins of Igneous Layering. D. Reidel, Dordrecht, pp. 473-503.

Inda, H.V. and Barbosa, F.F., 1978. Mapa geológico do Estado da Bahia, 1:1.000.000, SME-CPM.

Inda, H.V. and 18 coworkers, 1976. Projeto Rochas Básicas e Ultrabásicas de Euclides da Cunha, Relatório Final, CPM-Prospec S.A., $19 \mathrm{v}$.

Jardim de Sá, E.F., 1984. Relatório interno ao Projeto Jacurici. SGM-SME, $17 \mathrm{pp}$.

Jardim de Sá, E.F., Arcanjo, C.J. and Legrand, J.M., 1982. Structural and metamorphic history of part of the highgrade terrain in the Curaçá valley, Bahia-Brazil. Rev. Bras. Geoc., 12: 251-262.

Julien, R., 1988. Magmatologie des trois phases d'édification du massif du Mont-Dore (Massif Central, France). Données volcanologiques sur le site de Croizat. Thèse de Doct., UPS-Orsay, 194 pp.

Kurepin, V.A., 1988. Solid-solution thermodynamics and biotite stability in the $\mathrm{Fe}-\mathrm{Mg}-\mathrm{KAlSi}_{3} \mathrm{O}_{8}-\mathrm{OH}$ system. Geochem. Int., 25: 103-112.

Lameyre, J. and Bowden, P., 1982. Plutonic rock types series: discrimination of various granitoid series and related rocks. J. Volcanol. Geotherm. Res., 14: 169_ 186.

Lameyre, J., Blak, R., Bonin, B., Bowden, P. and Giret, A., 1982. The granitic terms of converging plutonic type series and associated mineralizations. In: X. Keqin and $T$. Guangchi (Editors), Proceedings on the International Symposium, Nanjing Univ. Science Press, Beijing, pp. 241-253.

Larsen, L.M., 1976. Clinopyroxenes and coexisting mafic minerals from the alkaline llímaussaq Intrusion, South Greenland. J. Petrol., 17: 258-290.

Leake, B.E., 1971. On aluminous and edenitic hornblendes. Mineral. Mag., 38: 389-407.

Leake, B.E., 1978. Nomenclature of amphiboles. Mineral. Mag., 42: 533-563.

Le Bel, L., 1979. Micas magmatiques et hydrothermaux dans l'environnement du porphyre cuprifère de Cerro Verde-Santa Rosa, Pérou. Bull. Minéral., 102: 35-41.

Leite, G.M.M. and Froés, R.J.B., 1989. Caracteristicas petroquimicas do granito alcalino Serra do Meio (Campo Alegre de Lurdes-Bahia ). Anais do II Congr. Bras. Geoq-SBGq, Rio de Janeiro, pp. 157-167.

Lindsley, D.H., 1983. Pyroxene thermometry. Am. Mineral., 68: 477-493.

Marinho, M.M., Silva, E.F.A. da, Lopes, G.A.D.C., Soares, 
J.V. and Cruz, M.J.M., 1979. Projeto Anagé-Caldeirão. CBPM. Conv. CBPM-SME., Relat. Final, v. 1, 225 pp.

Martin, R.F., 1988. The feldspar mineralogy of granites and rhyolites: a generalized case pseudomorphism of the magmatic phase. Rend. Soc. Ital. Mineral. Petrol. 43-2: 343-354.

Martin, R.F. and Bonin, B., 1976. Water and magma genesis: the association hypersolvus granite-subsolvus granite. Can. Mineral., 14: 188-237.

Mascarenhas, J. de F., 1972. Projeto Bahia, Salvador, DNPM/CPRM, $1^{\circ}$ fase, 5 v. e relatório da 2 fase $2 v$.

Mascarenhas, J. de F., 1975. Projeto Bahia, Salvador, DNPM/CPRM, folh. Sr. do Bomfim. rel. final. $1 \mathrm{v}$.

Mascarenhas, J. de F., 1979. Evolução geotectônica do precambriano do Estado da Bahia. In: Geologia e Recursos Minerais do Estado da Bahia. Textos Básicos, Salvador, SME/CPM, 2: 57-165

Maury, R.C., Brousse, R., Villemant, B., Joron, J.L., Jaffezic, $H$. and Treuil, M., 1980. Cristallisation fractionnée d'un magma basaltique alcalin: la série de la chaîne des Puys (Massif Central, France), I. Minéralogie et Pétrologie. Bull. Mineral., 103: 250-266.

Morimoto, N., 1989. Nomenclature of pyroxenes. Mineral. Mag., 52: 535-550.

Neumann, E.-R., 1976a. Compositional relations among pyroxenes, amphiboles and other mafic phases in Oslo region plutonic rocks. Lithos, 9: 85-109.

Neumann, R.-R., 1976b. Two refinements for the calculation of structural formulae for pyroxenes and amphiboles. Nor. Geol. Tidsskr., 56: 1-6.

Oftedahl, C., 1978. Cauldrons of the Permian Oslo rift. I. Volcanol. Geotherm. Res., 3: 343-371.

O'Halloran, D.A., 1985. Ras ed Dom migrating ring complexes: A-type granites and syenites from the Bayuda Desert, Sudan. J. Afr. Earth Sci., 3: 61-75.

Pearce, J.A., Harris, N.B.W. and Tindle, A.G., 1984. Trace element discrimination diagrams for the tectonic interpretation of granitic rocks. J. Petrol., 25: 956-983.

Robert, J.L., 1976a. Phlogopite solid solutions in the system $\mathrm{K}_{2} \mathrm{O}-\mathrm{MgO}-\mathrm{Al}_{2} \mathrm{O}_{3}-\mathrm{SiO}_{2}-\mathrm{H}_{2} \mathrm{O}$. Chem. Geol., 17: 195-212.

Robert. J.L., 1976b. Titanium solubility in synthetic phlogopite solid solutions. Chem. Geol., 17: 213-227.

Seifert, F. and Schreyer, W., 1971. Synthesis and stability of micas in the system $\mathrm{K}_{2} \mathrm{O}-\mathrm{MgO}-\mathrm{SiO}_{2}-\mathrm{H}_{2} \mathrm{O}$ and their relations to phlogopite. Contrib. Mineral. Petrol.. 30: $196-215$.

Silva, A.B., Liberal, G.S., Grossi Sad, J.H., Issa Filho, A., Rodrigues, C.S. and Riffel, B.F., 1988. Geologia e petrologia do complexo Angico dos Dias (Bahia, Brasil): Uma associação carbonatitica precambriana. Geochim. Bras., 2: 81-108.

Sorensen, H., 1974. The Alkaline Rocks. Wiley, London, $622 \mathrm{pp}$

Spear, F.S., 1981. An experimental study of hornblende stability and compositional variability in amphibolite. Am. J. Sci., 281: 697--734
Spencer, K.J. and Lindsley, D.H., 1981. A solution model for coexisting iron-titanium oxides. Am. Mineral., 66: 1189-1201.

Stephenson, D., 1972. Alkali clinopyroxenes from nepheline syenites of the South Qôroq Centre, South Greenland, Lithos, 5: 187-201.

Stephenson, D. and Upton, B.G.J., 1982. Ferromagnesian silicates in a differentiated alkaline complexe: Kûngnât Fjeld, South Greenland. Mineral. Mag. 46: 283-300.

Streckeisen, A.L.. 1976. To each plutonic rock its proper name. Earth Sci. Rev., 12:1-33.

Tanner de Oliveira, Ma A.F. and Jesus, V.F, 1979. Petrologia dos sienitos e granitos de Ipirá-Bahia. Anais XI Simp. Geo. Nordeste, Natal-RGN, pp. 317-331.

Thy, P., Jacobsen, N.N. and Wilson, J.R., 1987. Fine-scale graded layers in the Fongen-Hyllingen Gabbroic complex, Norway. Can. Mineral., 26: 235-243.

Thornton, C.P. and Tuttle, O.F., 1960. Chemistry of ig. neous rocks, I. Differentiation index. Am. J Sci., 258: 664-684

Tuttle, O.F. and Bowen, N.L., 1958. Origin of granite in the light of experimental studies in the system $\mathrm{Na}$. $\mathrm{Si}_{3} \mathrm{O}_{8}-\mathrm{KAlSi}_{3} \mathrm{O}_{8}-\mathrm{SiO}_{2}-\mathrm{H}_{2} \mathrm{O}$. Geol. Soc. Am. Mem. 74. $153 \mathrm{pp}$.

Tyler, R.C. and King, B.C., 1967. The pyroxenes of the alkaline igneous complexes of Eastern Uganda. Mineral. Mag., 280: 5-22.

Upton, B.G.J., 1974. The alkaline province of south-west Greenland. In: H. Sørensen (Editor), The Alkaline Rocks. Wiley, London, pp. $221-238$.

Varet, J., 1969. Les pyroxènes des phonolites du Cantal (Auvergne-France). Neues Jahrb. Mineral. Abh.. 4: $174-184$.

von Platen, H., 1965. Kristallisation granitischer Schmelzen. Beitr. Mineral. Petrogr., 11: 334-381.

Vorma, A., 1976. On the petrochemistry of rapakivi granites with special reference to the Laitila massif, south western Finland. Geol. Surv. Fin. Bull., 285. 98 pp.

Wagner, C., Velde, D. and Mokhtari, A., 1987. Sectorzoned phlogopites in igneous rocks. Contrib. Mineral. Petrol., 96: 186-191.

Watson, E.B., 1979. Apatite saturation in basic to intermediate magmas. Geophys. Res. Lett., 6: 937-949.

Watson, E.B., 1980. Apatite and phosphorus in mantlc source regions: an experimental study of apatite $/ \mathrm{melt}$ equilibria at pressures to $25 \mathrm{kbar}$. Earth. Planet. Sci. Lett., 51: 322-335.

Widmark, E.T., 1974. An edenite-forming reaction: hydrothermal experiments. Neues Jahrb. Mineral. Abh. 7: 323-329.

Winkler, H.G.F., 1967. Petrogenesis of Metamorphic Rocks. Springer-Verlag, New York, Berlin, 2nd ed.

Wones, D.R. and Eugster, H.P., 1965. Stability of biotite: experimental, theory, and application. Am. Mineral. 50: $1228-1272$.

Wones, D. and Gilbert, M.C., 1981. Amphiboles in the igneous environment. Rev. Mineral., 9B: 355-390. 